\title{
Selection of Bacteriocinogenic Bacillus spp. from Traditional Fermented Korean Food Products with Additional Beneficial Properties
}

\author{
Gee Hyeun Choi ${ }^{1}$, Joanna Ivy Irorita Fugaban ${ }^{1}$, Clarizza May Dioso ${ }^{2}$, Jorge Enrique Vazquez Bucheli ${ }^{1}(\mathbb{D}$, \\ Wilhelm Heinrich Holzapfel ${ }^{1,3(1)}$ and Svetoslav Dimitrov Todorov ${ }^{1, *(1)}$ \\ 1 ProBacLab, Department of Advanced Convergence, Handong Global University, Pohang 37554, Korea; \\ geehyun12@gmail.com (G.H.C.); jifugaban@up.edu.ph (J.I.I.F.); jorge_jbv@hotmail.com (J.E.V.B.); \\ wilhelm@woodapple.net (W.H.H.) \\ 2 HEM Pharma Inc., Pohang 37554, Korea; clarizza@hempharma.bio \\ 3 Human Effective Microbes, Department of Advanced Convergence, Handong Global University, \\ Pohang 37554, Korea \\ * Correspondence: slavi310570@abv.bg; Tel.: +82-10-3490-3152
}

check for updates

Citation: Choi, G.H.; Fugaban, J.I.I.; Dioso, C.M.; Vazquez Bucheli, J.E.; Holzapfel, W.H.; Todorov, S.D. Selection of Bacteriocinogenic Bacillus spp. from Traditional Fermented Korean Food Products with Additional Beneficial Properties. Fermentation 2021, 7, 271. https:// doi.org/10.3390/fermentation7040271

Academic Editor: Alicia Paz

Received: 19 September 2021 Accepted: 19 November 2021 Published: 21 November 2021

Publisher's Note: MDPI stays neutral with regard to jurisdictional claims in published maps and institutional affiliations.

Copyright: (c) 2021 by the authors. Licensee MDPI, Basel, Switzerland. This article is an open access article distributed under the terms and conditions of the Creative Commons Attribution (CC BY) license (https:/ / creativecommons.org/licenses/by/ $4.0 /)$.

\begin{abstract}
Two Bacillus spp. isolated from kimchi, Bacillus tequilensis ST816CD and Bacillus subtilis ST830CD, were characterized for their antimicrobial properties and safety. The proteinaceous nature of their inhibitory metabolites was confirmed after exposure to proteolytic enzymes, resulting in partial loss of the antimicrobial effect. This indicated that different non-proteinaceous antimicrobial substances may also be produced by these strains. This hypothesis was later confirmed when genes associated with the production of surfactants were detected in their DNA. The expressed antimicrobial metabolites were not affected by treatment at different temperatures and $\mathrm{pH}$ levels, including exposure to selected chemicals. Their strong adherence to susceptible pathogens was not significantly affected by different temperatures, chemicals, or $\mathrm{pH}$ values. Both Bacillus strains showed inhibitory activity against clinical and food-associated pathogens, including Listeria monocytogenes ATCC 15313, and some Staphylococcus species. Several genes associated with the production of antimicrobial metabolites were detected, but key virulence and beneficial genes were not present in these strains. Even though only B. tequilensis ST816CD displayed $\gamma$-hemolysin production, both selected strains were found to produce gelatinase and biogenic amines, which are considered as either potential virulence- or health-related factors. Moreover, the strains were susceptible to a variety of antibiotics except for the penicillin G [1 IU/disc] resistance of B. tequilensis ST816CD. Both strains showed proteolytic activity. Additionally, both strains showed low hydrophobicity based on bacterial adherence measured by hydrocarbons ( $n$-hexadecane).
\end{abstract}

Keywords: Bacillus tequilensis; Bacillus subtilis; bacteriocins; proteolytic activity; beneficial and virulence profile

\section{Introduction}

In the search for a healthier lifestyle, traditional fermented food products have become a major area for "strain-prospecting". In the past decade, different bacterial species involved in food fermentations were evaluated for their beneficial properties and for potential application in food biotechnology and as probiotic candidates for human and animal applications. However, strain-based safety evaluation is an essential milestone in the recommendation for the application of a new strain. In fact, several questions still need to be answered on the boundaries between beneficial properties, safety of the strains, and realistic functional applications as bio-protective agents, or as starter and/or probiotic cultures.

Bacillus spp. are rod-shaped, Gram-positive, catalase-producing bacteria, ubiquitously found in the environment, including soil, plant materials, fermented food products, and 
intestinal tracts of humans and animals, and are either obligate aerobic or facultative anaerobic microorganisms [1]. Because of their diverse physiological properties, these microorganisms have a higher viability and resistance potential [2]. Consequently, representatives of Bacillus spp. constitute great potential for research towards diverse applications in pharmaceutical and food processing industries [3]; this is also based on their established roles in the production of different traditional fermented food products [4]. For centuries, such strain mixtures were empirically "used" as starter cultures in the traditional production of fermented food products in Africa [4], Japan [5], and India [6]. Recently, Bacillus spp. were widely explored by the biotechnical industry for the potential production of bioactive metabolites, including amino acids, antibiotics, bacteriocins, surfactants, and bioactive peptides $[7,8]$. Several Bacillus spp. were described as producers of antimicrobial peptides (bacteriocins) [8-10] and further applied as commercial probiotics for humans and animals $[11,12]$. However, some representatives of the genus Bacillus are well known as pathogens and toxinogens based on the production of toxins or by their association with food spoilage. These include the species Bacillus anthracis and Bacillus cereus, and strains of Bacillus licheniformis that are associated with serious health conditions of humans and animals $[13,14]$.

Whereas antibiotics produced by some Bacillus spp. have been explored in the past few decades, only a limited number of studies addressed bacteriocins formed by Bacillus spp. Bacteriocins are ribosomally produced peptides and proteins with antimicrobial properties, and are post-translationally modified and active against closely related species [15]. It was reported that bacteriocins can be produced by different Gram-positive and Gram-negative bacteria, but the main focus of researchers thus far has been on the lactic acid bacteria (LAB) [16]. Moreover, increasing reports on the bacteriocins produced by different Bacillus spp. showed their potential as not only effective metabolites applied in the bio-control of pathogenic bacteria, but also as alternatives to antibiotics in the food and healthcare industries [17].

The objectives of this project were to isolate, differentiate, identify, and characterize bacteriocin-producing strains for bio-control of Listeria monocytogenes and Staphylococcus spp., both of which are identified to be clinically significant and/or food-associated pathogens. In addition, safety properties and the potential application of selected strains as therapeutical agents in human and veterinary medicine and/or food bio-preservation were also investigated.

\section{Materials and Methods}

\subsection{Isolation of Antibacterial Strains and Examination of Their Inhibitory Activity}

Samples of two Korean artisanal fermented food products, kimchi and gochujang, were obtained from the local market (Pohang, Korea) and transported to the laboratory under refrigerated conditions in a polystyrene box with ice packs. Food samples were homogenized in sterile saline solution $(0.85 \% \mathrm{NaCl}, w / v)$ in the proportion of 1:9 (sample:solution) (Stomacher 400 Circulator, Worthing, West Sussex, UK), and serially $10 \times$ diluted with the same diluents. Bacterial suspensions were plated on de Man, Rogosa and Sharpe (MRS, Becton, Dickinson, and Company-BD, Sparks, MD, USA), supplemented with $2 \%$ agar, $\mathrm{m} / \mathrm{v}$ (LPS Solution, Daejeon, Korea), and covered with a layer of $2 \%$ agar. Plates were cultured at $37^{\circ} \mathrm{C}$ for $24-48 \mathrm{~h}$ under aerobic conditions to observe well-distinguishable and individual colonies and also to determine the approximate $\mathrm{CFU} / \mathrm{mL}$. Plates were covered with an additional layer of Brain Heart Infusion (BHI, BD) supplemented with $1 \%$ agar and each of the following test microorganisms: L. monocytogenes ATCC 15313, Staphylococcus simulans KACC 13241, Staphylococcus carnosus subsp. carnosus KACC 13250, and Staphylococcus auricularis KACC 13252 at a final concentration of $10^{5} \mathrm{CFU} / \mathrm{mL}$ and cultured for additional $24 \mathrm{~h}$ at $37^{\circ} \mathrm{C}$. The plates were then examined for the presence of colonies with clear inhibition zones. Colonies of interest (representing inhibition zones of at least $2 \mathrm{~mm}$ ) were selected and evaluated for purity by culturing on MRS agar at $37^{\circ} \mathrm{C}$ for $24 \mathrm{~h}$ according to appropriate microbiological practices. Individual isolates were 
characterized by macroscopic and microscopic morphology and Gram staining, along with physiological characteristics including gas production and catalase reaction, according to recommendations from Bergey's Manual of Systematic Bacteriology of Archaea and Bacteria [18]. Pure bacterial cultures were stored at $-80{ }^{\circ} \mathrm{C}$ in the presence of $30 \%$ glycerol.

Pure cultures were evaluated for the production of antimicrobials according to dos Santos et al. [19]. Individual cultures were grown in MRS broth at $37^{\circ} \mathrm{C}$ for $24 \mathrm{~h}$ and cell-free supernatant (CFS) was obtained by centrifugation $\left(6000 \times \mathrm{g}, 10 \mathrm{~min}, 20^{\circ} \mathrm{C}\right)$. The obtained CFS was heat-treated $\left(10 \mathrm{~min}, 80^{\circ} \mathrm{C}\right)$ and spotted $(10 \mu \mathrm{L})$ on the surface of previously prepared BHI plates supplemented with $1 \%$ agar and mixed with an aliquot of test organism at a final concentration of $10^{5} \mathrm{CFU} / \mathrm{mL}$. Plates were incubated at $37^{\circ} \mathrm{C}$ for $24 \mathrm{~h}$ and investigated for inhibition zones. Clearing zones of at least $2 \mathrm{~mm}$ in diameter were considered as positive evidence for the potential production of antimicrobial metabolites.

To determine the level of produced bacteriocin/s, serial two-fold dilutions of CFS (as described before) were prepared with $100 \mathrm{mM}$ sodium phosphate buffer at $\mathrm{pH}$ 6.5, and $10 \mu \mathrm{L}$ of each dilution was spotted on the surface of the BHI agar plates prepared with the test microorganisms at a final concentration of $10^{5} \mathrm{CFU} / \mathrm{mL}$. Plates were incubated at $37^{\circ} \mathrm{C}$ for $24 \mathrm{~h}$ and studied for the formation of inhibition zones. Levels of expressed bacteriocins were presented as arbitrary units $(\mathrm{AU} / \mathrm{mL})$, taking into consideration the reciprocal of the highest dilution showing an inhibitory zone of at least $2 \mathrm{~mm}$ in diameter and the volume of deposited material according to the equation [20] $\mathrm{AU} / \mathrm{mL}=\left(\mathrm{D}^{n} \times\right.$ $1000) / \mathrm{p}$, where $\mathrm{D}=$ types of dilution, $n=$ the last dilution having at least $3 \mathrm{~mm}$ inhibition zone in diameter, and $\mathrm{p}=$ volume of CFS spotted on the plate $(\mu \mathrm{L})$.

\subsection{Differentiation and Identification of Selected Isolates}

Bacterial cultures confirmed to be producers of antimicrobial metabolites were grown in $20 \mathrm{~mL}$ MRS at $37^{\circ} \mathrm{C}$ for $24 \mathrm{~h}$ and DNA was isolated by applying the ZR Fungal/Bacterial DNA Kit (Zymo Research, Irvine, CA, USA) according to the manufacturer's instructions. DNA purity and concentration were determined by NanoDrop (Spectrostarnano, Ortenberg, Germany).

Differentiation of the selected isolates was performed according to de Moraes et al. [21] by conducting rep-PCR and RAPD-PCR analysis on a Veriti 96-well thermal cycler (Thermo Fisher, Waltham, MA, USA). The obtained amplicons were separated on $1.5 \%$ agarose gels $(w / v)$ stained with SYBR ${ }^{\circledR}$ Safe DNA gel stain (Thermo Fisher Scientific, Waltham, MA, USA) by gel electrophoresis (GH-200 Genera Biosystems, Victoria, Australia; Elite 300 Plus Power Supply, Wealtec Bioscience Co., Ltd., Taiwan) equipment and visualized in OmegaLumG gel documenter (Aplegen, Inc., San Francisco, CA, USA) equipment.

Selected unique strains from the previous step were subjected to 16S rRNA partial sequencing by a commercial service (Solgent Co., Ltd., Daejeon, Korea). The obtained nucleotide sequences were interpreted by the Basic Local Alignment Search Tool (BLAST, GenBank, National Center for Biotechnology Information, Bethesda, MD, USA).

\subsection{Evaluation on Proteinaceous Nature and Stability of Produced Bacteriocins}

To confirm the proteinaceous nature of the produced antimicrobial metabolites, CFS samples from the studied strains were obtained as described before. Corresponding CFS was treated with $0.1 \mathrm{mg} / \mathrm{mL}$ of Proteinase $\mathrm{K}$, $\alpha$-chymotrypsin, and $\alpha$-amylase (all from Sigma-Aldrich, St. Louis, MO, USA), individually, for $2 \mathrm{~h}$ at $37^{\circ} \mathrm{C}$ followed by heat treatment at $98^{\circ} \mathrm{C}$ for $3 \mathrm{~min}$ to stop the enzymatic reaction. Each $10 \mu \mathrm{L}$ of the treated CFS was spotted on the surface of the BHI agar plates prepared with the test microorganisms as described before. Antimicrobial activity of the treated CFS against L. monocytogenes ATCC 15313 , S. simulans KACC 13241, S. carnosus subsp. carnosus KACC 13250, and S. auricularis KACC 13252 were tested as described before, in addition to CFS, untreated by enzymes and solutions of the evaluated enzymes, serving as positive control. Experiments were performed in duplicates on two independent occasions. 
For the evaluation of the effect of $\mathrm{pH}(2.0,4.0,6.0,8.0$, and 10.0), using different temperatures $\left(4,25,30,37,60,80\right.$, and $\left.100{ }^{\circ} \mathrm{C}\right)$ and selected chemicals commonly used in the food industry ( $\mathrm{NaCl}$, Tween 80 , SDS, and skim milk) on bacteriocin activity, CFS samples from the studied strains prepared as described before were incubated at the mentioned temperatures and $\mathrm{pH}$ values for $2 \mathrm{~h}$ and with chemicals for $1 \mathrm{~h}$, respectively. The $\mathrm{pH}$ of the CFS was corrected with $1 \mathrm{M} \mathrm{NaOH}$ or $1 \mathrm{M} \mathrm{HCl}$ and $1 \%$ of the chemicals were added to each CFS sample. All samples were incubated at $37^{\circ} \mathrm{C}$. For the CFS treated at different $\mathrm{pH}$ levels, the $\mathrm{pH}$ of all groups was readjusted to 5.5-6.5 after incubation in order to prevent the effect of acid on activity. Each $10 \mu \mathrm{L}$ aliquot of the treated CFS was spotted on the surface of the BHI agar plates prepared with the test microorganisms as described before. Antimicrobial activity was determined against the previously described test panel.

\subsection{Production of Antimicrobials and Change of $\mathrm{pH}$ during Bacterial Growth}

Acidification profiles and production of antimicrobials during bacterial growth were evaluated for the studied strains according to dos Santos et al. [19]. The selected bacterial strains were grown in MRS broth at $37^{\circ} \mathrm{C}$ for $24 \mathrm{~h}$ under aerobic conditions. The overnight cultures were subsequently inoculated into $100 \mathrm{~mL}$ of MRS broth $(5 \%, v / v)$ and incubated at $37^{\circ} \mathrm{C}$. At every selected time interval $(1 \mathrm{~h}$ for recording of growth and $\mathrm{pH}$ and $3 \mathrm{~h}$ for the antimicrobial activity test), the required volume of a culture was withdrawn and bacterial growth was recorded by observing changes in the OD, determined at $600 \mathrm{~nm}$ on Optizon Pop Bio (Mecasys Co., Daejeon, Korea). The $\mathrm{pH}$ values were recorded using a $\mathrm{pH}$ meter ST3100 (Ohaus Co., Parsippany, NJ, USA). Antimicrobial activity was determined and expressed as $\mathrm{AU} / \mathrm{mL}$ as described before, against the panel test microorganisms previously described. Experiments were performed in duplicates on two independent occasions.

\subsection{The Effect of CFS on Growth and Survival of the Target Strains}

The selected test microorganisms sensitive to the studied bacteriocins were inoculated at a level of $5 \%$ in $100 \mathrm{~mL}$ of $\mathrm{BHI}$ and incubated at $37^{\circ} \mathrm{C}$. Changes in bacterial growth of the test microorganisms were monitored every $1 \mathrm{~h}$ at $600 \mathrm{~nm}$ using Optizon Pop Bio spectrophotometer. Furthermore, $20 \%$ of filter-sterilized $\left(0.22 \mu \mathrm{m}\right.$ of Minisart ${ }^{\circledR}$ syringe filter, Sartorius AG, Göttingen, Germany) CFS (v/v) (step applied only for the specificity of this experiment) produced by selected Bacillus strains obtained after growth in MRS at $37^{\circ} \mathrm{C}$ for $24 \mathrm{~h}$ was added to the test microorganisms at the beginning of the early exponential growth phase ( $3 \mathrm{~h}$ after incubation). The growth of the test organisms without the addition of antimicrobials served as a control. Experiments were performed in duplicates on two independent occasions.

\subsection{Adhesion Properties}

Adhesion of the produced antimicrobials to a panel of sensitive and resistant test microorganisms was evaluated according to the method proposed by Todorov and Dicks [22]. The studied strains were grown in MRS broth for $24 \mathrm{~h}$ at $37^{\circ} \mathrm{C}$ and CFS was prepared from overnight cultures as described before. In addition, CFS was filter-sterilized via $0.22 \mu \mathrm{m}$ filters. The test microorganisms used for the evaluation of adherence properties of the obtained antimicrobials are listed in Table 1. Bacterial strains were grown in BHI or MRS broth, accordingly, and incubated at $37^{\circ} \mathrm{C}$ for $24 \mathrm{~h}$. Overnight cells were obtained by centrifugation $\left(4000 \times \mathrm{g}, 10 \mathrm{~min}, 20^{\circ} \mathrm{C}\right)$ and re-suspended in sterile saline solution $(0.85 \% \mathrm{NaCl}, w / v)$ adjusting to $\mathrm{OD}$ of 1.0 at $600 \mathrm{~nm}$. Equal volumes of the obtained cell suspensions and CFS prepared as described before were mixed (ratio of 1:1) and incubated for $1 \mathrm{~h}$ at $37^{\circ} \mathrm{C}$, followed by centrifugation $\left(400 \times g, 10 \mathrm{~min}, 20^{\circ} \mathrm{C}\right)$ and treatment of the obtained CFS at $80^{\circ} \mathrm{C}$ for 10 . Residual bacteriocin activity was determined by two-fold dilution of the CFS and the activity was expressed as AU/ml against $S$. simulans KACC 13241 as described earlier. Adherence levels of the bacteriocins to a selected group of the test microorganisms was expressed as $\%$ of adherence $=100-[(\mathrm{A} / \mathrm{B}) \times 100]$, where $\mathrm{A}$ is 
bacteriocin activity after treatment in $\mathrm{AU} / \mathrm{mL}$ and $\mathrm{B}$ is bacteriocin activity before treatment in $\mathrm{AU} / \mathrm{mL}$.

Table 1. Evaluation of the effect of environmental factors on the adherence properties of the bacteriocins produced by Bacillus tequilensis ST816CD and Bacillus subtilis ST830CD.

\begin{tabular}{|c|c|c|c|}
\hline \multirow[t]{2}{*}{ Test Organisms } & \multirow[t]{2}{*}{ Environmental Factor } & \multicolumn{2}{|c|}{ Effect of Factors on } \\
\hline & & $\begin{array}{l}\text { B. tequi- } \\
\text { lensis } \\
\text { ST816CD }\end{array}$ & $\begin{array}{l}\text { B. subtilis } \\
\text { ST830CD }\end{array}$ \\
\hline Lactobacillus rhamnosus 911 & & $50^{\#}$ & 50 \\
\hline Lactobacillus brevis 384 & & 0 & 0 \\
\hline Lactobacillus plantarum 187 & & 0 & 0 \\
\hline Lactobacillus plantarum 211 & & 50 & 50 \\
\hline Lactobacillus fermentum 792 & & 0 & 0 \\
\hline Lactobacillus salivarius 851 & & 0 & 50 \\
\hline Pediococcus acidilactici 867 & & 0 & 50 \\
\hline Streptococcus sanguinis KACC 11301 & & 75 & 75 \\
\hline Streptococcus mutans KACC 16833 & & 0 & 50 \\
\hline Streptococcus mitis KACC 16832 & & 0 & 0 \\
\hline Escherichia coli ATCC 25922 & & 50 & 75 \\
\hline Listeria monocytogenes ATCC 15313 & & 75 & 94 \\
\hline Staphylococcus simulans KACC 13241 & & 75 & 94 \\
\hline \multirow[t]{2}{*}{ Staphylococcus auricularis KACC 13252} & & 50 & 50 \\
\hline & Temperature, ${ }^{\circ} \mathrm{C}$ & & \\
\hline \multirow[t]{4}{*}{ Listeria monocytogenes ATCC 15313} & 25 & 50 & 0 \\
\hline & 30 & 50 & 0 \\
\hline & 37 & 50 & 50 \\
\hline & 40 & 0 & 50 \\
\hline \multirow[t]{5}{*}{ Staphylococcus simulans KACC 13241} & 25 & 50 & 0 \\
\hline & 30 & 50 & 50 \\
\hline & 37 & 50 & 75 \\
\hline & 40 & 0 & 50 \\
\hline & $\mathrm{pH}$ & & \\
\hline \multirow[t]{3}{*}{ Listeria monocytogenes ATCC 15313} & 4.0 & 50 & 50 \\
\hline & 6.0 & 50 & 50 \\
\hline & 8.0 & 50 & 50 \\
\hline \multirow[t]{4}{*}{ Staphylococcus simulans KACC 13241} & 4.0 & 50 & 0 \\
\hline & 6.0 & 50 & 0 \\
\hline & 8.0 & 0 & 0 \\
\hline & Additives & & \\
\hline \multirow[t]{3}{*}{ Listeria monocytogenes ATCC 15313} & skim milk* & 50 & 75 \\
\hline & enzyme salts ${ }^{* *}$ & 75 & 75 \\
\hline & oral hygienic powder $* * *$ & 50 & 75 \\
\hline \multirow[t]{3}{*}{ Staphylococcus simulans KACC 13241} & skim milk* & 75 & 50 \\
\hline & enzyme salts $* *$ & 75 & 50 \\
\hline & oral hygienic powder ${ }^{* * *}$ & 75 & 0 \\
\hline
\end{tabular}

\# Results were expressed as \% adherence of the studied bacteriocins to the evaluated test strain; ${ }^{\text {skim milk, Difco; }}$ ** component for the preparation of Cleaning Time Ocean Mint, Bareun. LLC, Chun-cheon, Korea; ${ }^{* * *}$ Cleaning Time Ocean Mint.

Moreover, the effects of $\mathrm{pH}$, temperature, and selected chemicals on the adherence of the studied bacteriocins to the selected test microorganisms (L. monocytogenes ATCC 15313 and S. simulans KACC 13241) were tested. The experiments were performed as described before with the following modifications: (a) for the evaluation of the effect of temperature, after pairing cell suspensions of the test microorganisms with the CFS in the equal amount, the mixed suspensions were incubated at $25,30,37$, and $40{ }^{\circ} \mathrm{C}$; (b) for the evaluation of the effect of $\mathrm{pH}$, cell suspensions of the test microorganisms were prepared in saline solution 
$(0.85 \% \mathrm{NaCl}, w / v)$ with $\mathrm{pH}$ adjusted to $4.0,6.0$, and, 8.0 , followed by addition of the CFS in the same proportion and incubation at $37^{\circ} \mathrm{C}$ for $1 \mathrm{~h}$. The $\mathrm{pH}$ of the obtained CFS was readjusted to $\mathrm{pH} 5.5-6.5$ and treated at $80{ }^{\circ} \mathrm{C}$ for $10 \mathrm{~min}$; (c) for the evaluation of the effect of selected chemicals when cell suspensions of the test microorganisms and the prepared CFS were combined, the respective chemicals and components such as skim milk, enzyme salts and oral hygienic powder were added at a final concentration of $1 \%(w / v)$, followed by incubation at $37^{\circ} \mathrm{C}$ for $1 \mathrm{~h}$.

\subsection{Spectrum of Activity}

Antimicrobial metabolites produced by the Bacillus strains were tested against the selected microbial panel from various culture collections of HGU (Handong Global University, Pohang, Korea), HEMPharma Inc. (Human Effective Microbes Pharma Inc., Pohang, Korea), ATCC (American Type Culture Collection, Manassas, VA, USA), KACC (Korean Agricultural Culture Collection, Jeollabuk-do, Korea), and KCTC (Korean Culture Type Collection, Jeongeup, Korea) in addition to L. monocytogenes ATCC 15313 and the selected Staphylococcus spp. used for the screening process, listed in Table 2. Bacterial inhibitory activity was evaluated by the agar spot test as mentioned before.

Table 2. Spectrum of activity of bacteriocin produced by Bacillus tequilensis ST816CD and Bacillus subtilis ST830CD.

\begin{tabular}{|c|c|c|}
\hline \multirow[b]{2}{*}{ Test Microorganisms } & \multicolumn{2}{|c|}{ Inhibition by CFS from } \\
\hline & B. tequilensis ST816CD & B. subtilis ST830CD \\
\hline Lactobacillus brevis HEM384 & - & - \\
\hline Lactobacillus fermentum HEM792 & - & - \\
\hline Lactobacillus plantarum HEM187 & - & - \\
\hline Lactobacillus plantarum HEM211 & + & - \\
\hline Lactobacillus plantarun ST8Sh & - & - \\
\hline Lactobacillus rhamnosus HEM911 & + & + \\
\hline Lactobacillus salivarius HEM851 & - & + \\
\hline Listeria monocytogenes ATCC 15313 & - & + \\
\hline Pediococcus acidilactici HEM867 & - & + \\
\hline Pediococcus acidilactici ST3522BG & - & - \\
\hline Pediococcus pentosaceus ST3633BG & - & - \\
\hline Staphylococcus arlettae KACC 13254 & + & + \\
\hline Staphylococcus auricularis KACC 13252 & + & + \\
\hline $\begin{array}{c}\text { Staphylococcus capitis subsp. capitis } \\
\text { KACC } 13242\end{array}$ & - & - \\
\hline $\begin{array}{c}\text { Staphylococcus carnosus subsp. carnosus } \\
\text { KACC } 13250\end{array}$ & + & + \\
\hline $\begin{array}{l}\text { Staphylococcus cohnii subsp. cohnii } \\
\text { KACC } 13237\end{array}$ & - & - \\
\hline Staphylococcus delphini KACC 13258 & + & - \\
\hline Staphylococcus epidermidis KACC 13234 & - & - \\
\hline Staphylococcus lentus KACC 13245 & + & - \\
\hline Staphylococcus simulans KACC 13241 & + & + \\
\hline Staphylococcus warneri KACC 13240 & - & - \\
\hline Streptococcus mitis KACC 16832 & - & - \\
\hline Streptococcus mutans KACC 16833 & - & - \\
\hline Streptococcus sanguinis KACC 11301 & + & + \\
\hline Escherichia coli ATCC 25922 & - & - \\
\hline
\end{tabular}

+: Positive inhibitory activity; -: without inhibitory activity.

\subsection{Presence of Genes Encoding for Antimicrobials}

Previously isolated DNA from the studied strains (Section 2.2.) was investigated for the presence of genes responsible for the production of different antimicrobials as mentioned in Table 3; primers used for respective PCR reactions and reference works are listed in Table 3. 
Table 3. Primers, references, and results of PCR reactions targeting the listed genes in the DNA obtained from Bacillus tequilensis ST816CD and Bacillus subtilis ST830CD.

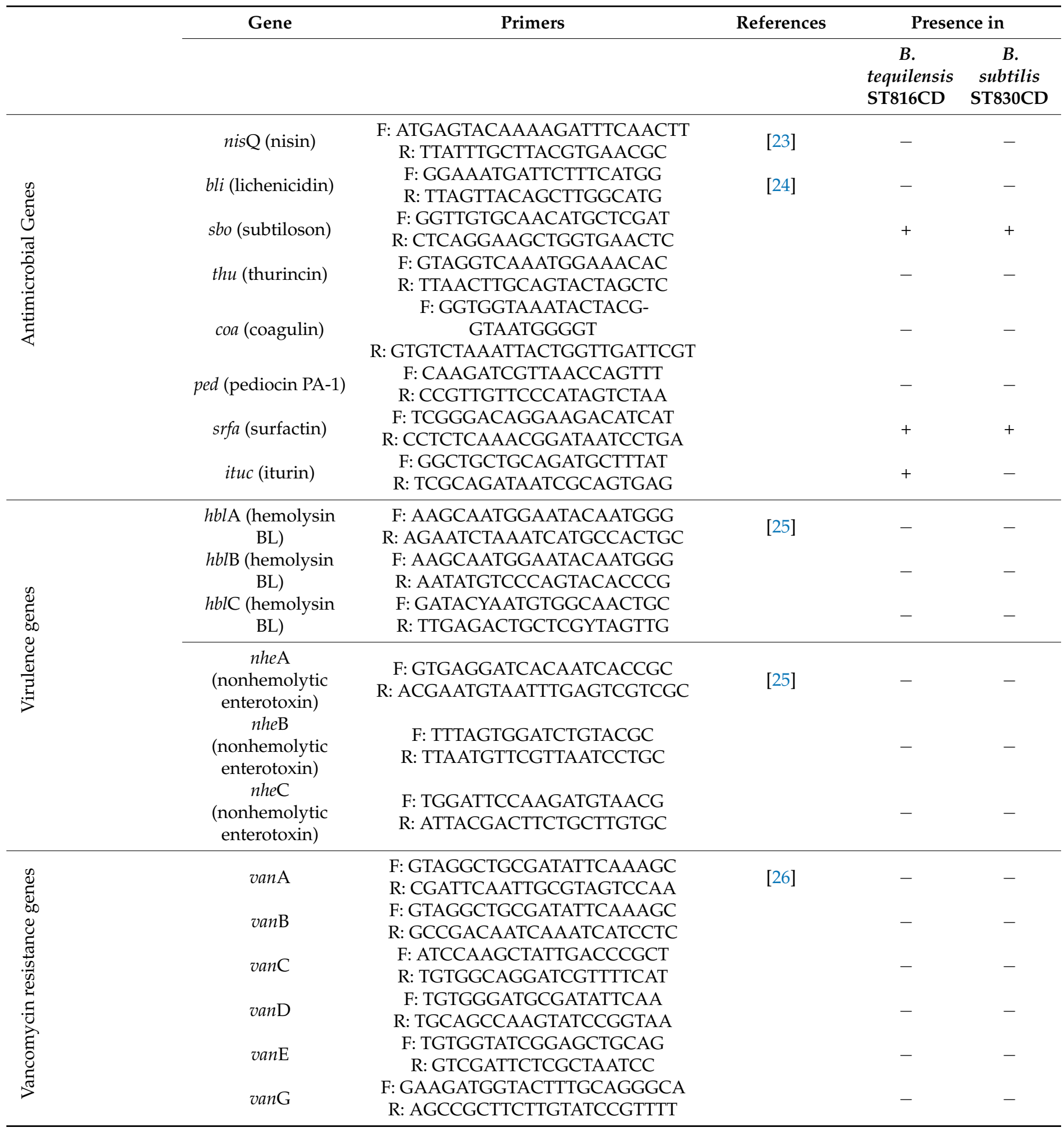


Table 3. Cont.

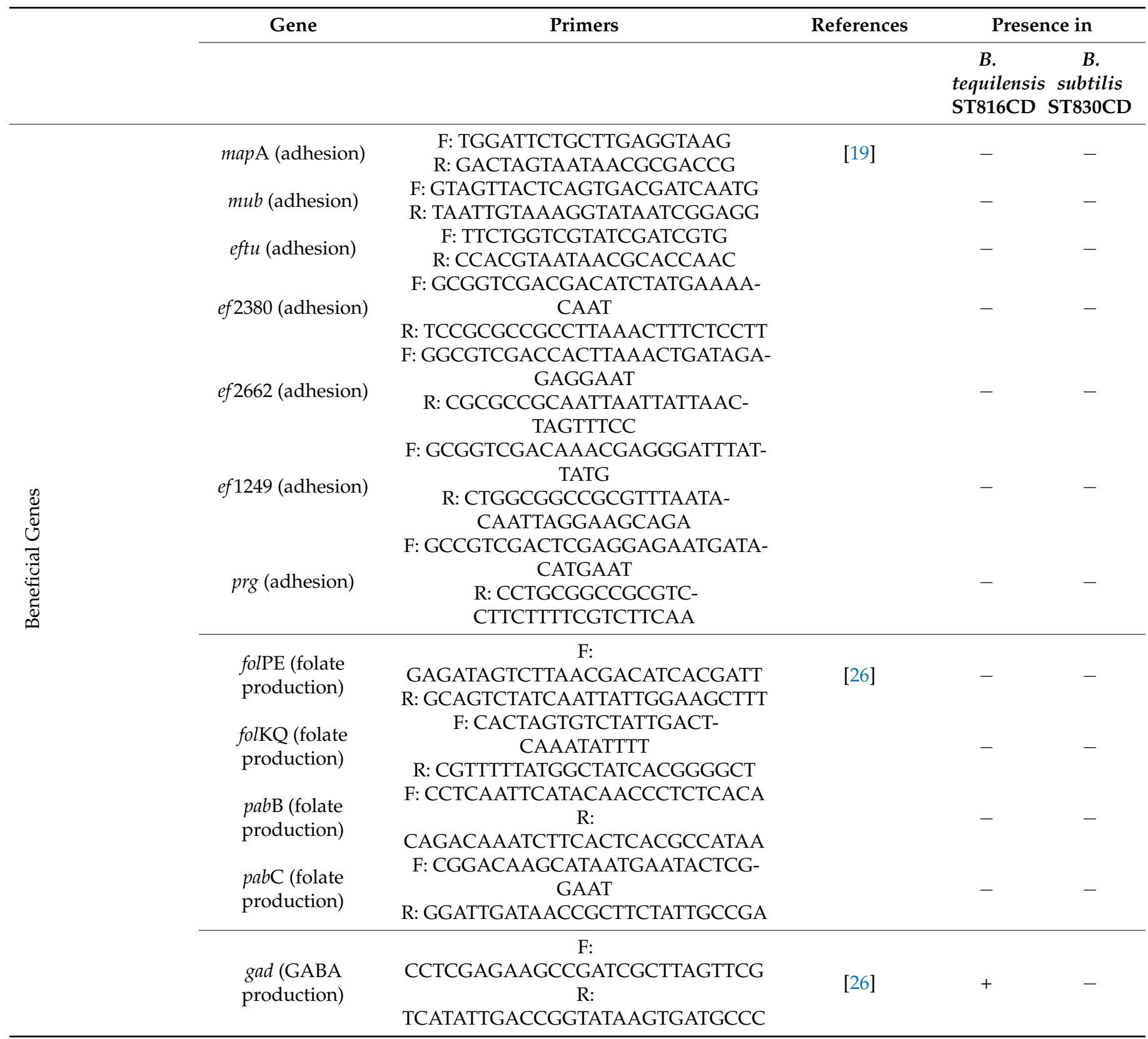

$+=$ presence of targeted gene; $-=$ absence of targeted gene.

\subsection{Safety Assessments}

\subsubsection{Virulence Genes}

Previously isolated DNA from the studied strains was evaluated for the presence of different virulence and vancomycin-resistance genes as mentioned in Table 3; primers used in each of the corresponding PCR-based screening assays are listed in Table 3.

\subsubsection{Biogenic Amines, Gelatinase, and Hemolytic Activity}

The selected Bacillus spp. Strains were evaluated for the production of biogenic amines, gelatinase production, and hemolytic activity according to Fugaban et al. [27], with some modifications. Biogenic amine production of the studied cultures was observed by subculturing the isolates in MRS broth supplemented with $0.1 \%$ of each precursor amino acid of the biogenic amines, comprising tyrosine, ornithine, lysine, and histidine (Sigma-Aldrich) in the proportion of 1:100 (50 $\mu \mathrm{L}$ cultures:5 mL MRS in this study) and 
incubated at $37^{\circ} \mathrm{C}$ for $24 \mathrm{~h}$ at least 5 times. A $10 \mu \mathrm{L}$ aliquot of each culture was properly spread on a plate supplemented with each precursor of biogenic amine (culture with tyrosine in the MRS agar plate with tyrosine) and all plates were incubated at $37^{\circ} \mathrm{C}$ for $24 \mathrm{~h}$. Changes in the color of the media from yellow to violet shows decarboxylation of the precursors indicated production of a biogenic amine. Lactobacillus plantarum ATCC 14917 and Escherichia coli ATCC 25922 were used as negative and positive controls, respectively.

For the assessment of gelatinase production, $10 \mu \mathrm{L}$ of the cultures was stabbed by an inoculation loop to the bottom of Luria Bertani (BD) with 2\% agar (LPS Solution) and $3 \%$ gelatin $(w / v)$ (Duksanpure chemicals Co., Ansan-si, Korea) in tubes and incubated for 2-4 days at $37^{\circ} \mathrm{C}$, followed by refrigeration (at $4{ }^{\circ} \mathrm{C}$ ) for $4 \mathrm{~h}$. Liquefication of the medium is considered as evidence of gelatin hydrolysis (a positive result for the production of gelatinase). Lb. plantarum ATCC 14917 and E. coli ATCC 25922 were used as negative controls, and B. cereus ATCC 27348 as a positive control.

For the hemolytic activity test, $10 \mu \mathrm{L}$ of each culture was streaked by an inoculation loop on the surface of Trypticase Soy Agar supplemented with 5\% defibrinated sheep blood $(v / v)$ (Synergy Innovation, Seongnam-si, Korea) and incubated at $37^{\circ} \mathrm{C}$ for $24 \mathrm{~h}$. B. cereus ATCC 27348 was used as positive $\beta$-hemolytic control (destruction of the red blood cells; distinct halos around the colonies), Streptococcus pneumoniae ATCC 49619 as an $\alpha$-hemolytic control (partial reduction of the red blood cells; green or brown halos around the colonies), and Lb. plantarum ATCC 14917 as a $\gamma$-hemolytic control (a lack of hemolysis; no discoloration around the colonies). All three experiments were performed in triplicate on two independent occasions.

\subsubsection{Antibiotics}

The selected strains were evaluated for their antibiotic resistance by disc diffusion assay (Oxoid, Basingstoke, Hampshire, UK) with the antibiotics listed in Table 4 . The strains were grown in MRS broth at $37^{\circ} \mathrm{C}$ for $24 \mathrm{~h}$ and incorporated into MRS plates with $2 \%$ agar at a final concentration of $10^{5} \mathrm{CFU} / \mathrm{mL}$. The antibiotic discs were placed on the surface of the plates and incubated at $37^{\circ} \mathrm{C}$ for $24 \mathrm{~h}$. Susceptibility to the tested antibiotics was interpreted according to the diameter of the inhibition zones $(\mathrm{mm})$ [28]. The tests were performed in triplicate.

\subsection{Detection of Beneficial Genes}

DNA isolated from each strain as described before was evaluated for the presence of some genes associated with beneficial properties (adhesion, folate, and GABA production) as listed in Table 3.

\subsection{Proteolytic Activity}

MRS agar plates supplemented with $10 \%$ skim milk (Difco) or $5 \%$ sodium caseinate (Sigma-Aldrich) were prepared. Overnight cultures of the studied strains were spotted on the surface of the plates and incubated for $24 \mathrm{~h}$ at $37^{\circ} \mathrm{C}$. The presence of a transparent area around the growing cultures on the MRS agar plates containing either milk or sodium caseinate was associated with the ability of a strain to hydrolyze milk and casein, respectively.

Production of 19 key enzymes was evaluated by APYZym kit (BioMerieux, Marcyl'Étoile, France) following the manufacturer's recommendations. 
Table 4. Safety evaluation of Bacillus tequilensis ST816CD and Bacillus subtilis ST830CD.

\begin{tabular}{ccc}
\hline & $\begin{array}{c}\text { B. tequilensis } \\
\text { ST816CD }\end{array}$ & $\begin{array}{c}\text { B. subtilis } \\
\text { ST830CD }\end{array}$ \\
\hline $\begin{array}{ccc}\text { Hemolytic activity } \\
(\alpha, \beta, \gamma)\end{array}$ & $\gamma$ & - \\
\hline Gelatinase & + & + \\
Biogenic amines: & + & + \\
histidine to histamine & + & + \\
ornithine to putrescine & + & + \\
lysine to cadaverine & + & 40 \\
tyrosine to tyramine & Diameter Inhibition Zone $(\mathrm{mm})$ \\
\hline Antibiotics & 25 & 45 \\
ampicillin $10 \mu \mathrm{g}$ per disc & 45 & 55 \\
ciprofloxacin $10 \mu \mathrm{g}$ per disc & 27 & 40 \\
clindamycin $10 \mu \mathrm{g}$ per disc & 29 & 30 \\
erythromycin $10 \mu \mathrm{g}$ per disc & 15 & 35 \\
gentamycin $10 \mu \mathrm{g}$ per disc & 0 & 25 \\
penicillin $\mathrm{G} 1 \mathrm{IU}$ per disc & 15 & 20 \\
streptomycin $10 \mu \mathrm{g}$ per disc & 15 & 30 \\
tobramycin $10 \mu \mathrm{g}$ per disc & 22 & \\
vancomycin $30 \mu \mathrm{g}$ per disc & & \\
\hline+ detection of gelatinase or biogenic amines production; $-=$ absence of gelatinase or biogenic amines production.
\end{tabular}

\subsection{Production of Lactic Acid}

The amount of lactic acid produced by each strain was evaluated enzymatically, applying DL-lactic acid assay kit and Mega-Calc ${ }^{\mathrm{TM}}$ Data Calculator (Megazyme, Bray, Wicklow, Ireland). These tests were performed in duplicate with the CFS of each strain grown in MRS broth at $37^{\circ} \mathrm{C}$ for $24 \mathrm{~h}$.

\subsection{Hydrophobicity}

For the determination of the hydrophobicity (one of cell surface properties; adherence to hydrocarbons) level of studied strains, the method proposed by Doyle and Rosenberg [29] with some modifications was applied. In summary, the strains were grown in MRS broth at $37^{\circ} \mathrm{C}$ for $24 \mathrm{~h}$. Cells were harvested by centrifugation $(4000 \times \mathrm{g}, 10 \mathrm{~min}$, $\left.4{ }^{\circ} \mathrm{C}\right)$, washed with potassium phosphate buffer $(50 \mathrm{mM}, \mathrm{pH} 6.5)$, and adjusted to about 1.0 unit of optical density $\left(\mathrm{OD}_{560 \mathrm{~nm}}\right)$ by re-suspending in the same buffer. The obtained cell suspension was mixed with $n$-hexadecane (Sigma-Aldrich) in the proportion of 5:1 ( $3 \mathrm{~mL}$ of suspension:0.6 $\mathrm{mL}$ of $n$-hexadecane in this study) and vortexed for $2 \mathrm{~min}$. The two phases were allowed to separate for $60 \mathrm{~min}$ at $37^{\circ} \mathrm{C}$. The $n$-hexadecane phase in the upper level was removed and the optical density $\left(\mathrm{OD}_{560 \mathrm{~nm}}\right)$ was determined as reading two of the hydrophilic phases. The percentage of hydrophobicity level was calculated as follows: \% hydrophobicity $=\left[\left(\mathrm{OD}_{560}\right.\right.$ reading $1-\mathrm{OD}_{560}$ reading 2$) / \mathrm{OD}_{560}$ reading 1$] \times$ 100. Experiments were performed in triplicate with independent cultures.

\section{Results}

\subsection{Isolation, Differentiation and Identification of Bacillus spp.}

Different traditional fermented food products, obtained from local markets in Pohang (Korea), were investigated as potential sources of beneficial microorganisms. Although the original aim of this study was to isolate lactic acid bacteria (LAB) from various fermented food products, the preliminary profiles of the isolated strains indicate that bacilli could be considered as major inhabitants of these Korean fermented food products (data not shown), since more than $80 \%$ of the evaluated plates were covered by typical Bacillus colonies. Based on the initial screening, 69 isolates were considered as promising candidates for bacteriocin production. The majority of the isolates showed the typical morphology of Bacillus spp. on MRS agar, observed as downy circles. They were also found to be rod-shaped Gram- 
positive bacteria and catalase producers when aerobically incubated. The selected 69 isolates were further evaluated for potential production of antimicrobial peptides, resulting in 14 confirmed potential producers of antimicrobial metabolites. The identity of bioactive molecules was further narrowed down by treatment of the studied CFS with proteolytic enzymes, thereby confirming 4 out of 14 isolates to be producers of non-proteinaceous antimicrobial metabolites. Based on preliminary inhibitory screening, only 2 of the 14 selected isolates were further studied as potential candidate bacteriocinogenic strains based on the preliminary spectrum of activity and levels of produced bacteriocins.

Based on the preliminary physiological and biochemical characteristics, the two selected isolates, ST816CD and ST830CD, were differentiated by rep-PCR (Figure 1) and considered as two different strains based on the obtained fingerprints. Moreover, partial sequencing of the $16 \mathrm{~S}$ rRNA gene revealed that ST816CD (isolated from radish kimchi) and ST830CD (isolated from chili paste) confirmed the identity of the strains as Bacillus tequilensis and B. subtilis, respectively.

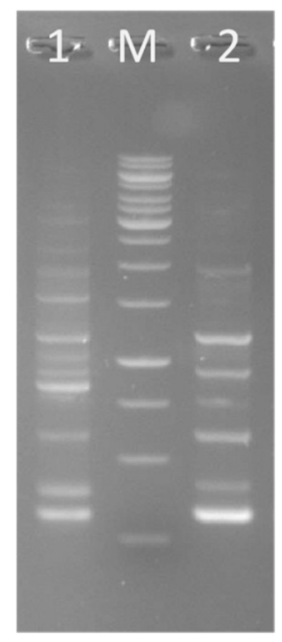

Figure 1. rep-PCR profile fingerprinting of (1) Bacillus tequilensis ST816CD, (2) Bacillus subtilis ST830CD, (M) 1 kB ladder (Thermo Fischer).

\subsection{Evaluation of the Antimicrobial Activity}

Effect of proteolytic enzymes and partial reduction of antimicrobial activity of the inhibitory metabolites produced by B. tequilensis ST816CD and B. subtilis ST830CD confirmed their proteinaceous nature (Table 5). However, residual activity was considered as an indication that these strains most probably also produce more than one antimicrobial metabolite. This is shown later in this study by the presence of genes encoding the production of surfactants. Moreover, bacteriocins produced by B. tequilensis ST816CD and B. subtilis ST830CD showed stability when exposed to diverse temperatures, chemicals, and of $\mathrm{pH}$ levels (Table 5). 
Table 5. Effect of enzymes and environmental factors (temperature, $\mathrm{pH}$, and some chemicals/medium components) on the stability of bacteriocin produced by B. tequilensis ST816CD and B. subtilis ST830CD. S. simulans KACC 13241, S. carnosus subsp. carnosus KACC 13250, S. auricularis KACC 13252 and L. monocytogenes ATCC 15313 were used as test organisms for the evaluation of bacteriocinogenic activity. Note: (+): bacteriocin is still active after treatment; $(-)$ : no bacteriocin activity was recorded after the treatment; $(+/-)$ : reduction of inhibition zone compared with untreated (control) bacteriocins.

\begin{tabular}{|c|c|c|}
\hline & \multicolumn{2}{|c|}{ Bacteriocins Formed by } \\
\hline & $\begin{array}{c}\text { Bacillus tequilensis } \\
\text { ST816CD }\end{array}$ & Bacillus subtilis ST830CD \\
\hline $\begin{array}{l}\text { Effect of enzymes: } \\
\text { proteinase } \mathrm{K} \\
\alpha \text {-chymotrypsin } \\
\alpha \text {-amylase }\end{array}$ & $\begin{array}{l}+/- \\
+/- \\
+\end{array}$ & $\begin{array}{l}+/- \\
+/- \\
+\end{array}$ \\
\hline $\begin{array}{c}\text { Effect of temperature }\left({ }^{\circ} \mathrm{C}\right) \text { : } \\
4,25,30,37,60,80,100 \\
\text { For } 1 \mathrm{~h} \\
\text { For } 2 \mathrm{~h}\end{array}$ & $\begin{array}{l}+ \\
+\end{array}$ & $\begin{array}{l}+ \\
+\end{array}$ \\
\hline $\begin{array}{c}\text { Effect of } \mathrm{pH}(\text { for } 2 \mathrm{~h}): \\
2.0 \\
4.0,6.0,8.0 \\
10.0\end{array}$ & $\begin{array}{l}+ \\
+ \\
-\end{array}$ & $\begin{array}{l}- \\
+ \\
+\end{array}$ \\
\hline $\begin{array}{c}\text { Effect of chemicals/medium } \\
\text { components (1\%; for } 1 \mathrm{~h}) \text { : } \\
\mathrm{NaCl} \text {, Tween } 80 \text {, SDS, skim milk }\end{array}$ & + & + \\
\hline
\end{tabular}

\subsection{Bacterial Growth, Acidification (Changes in $p H$ ) and Production of Bacteriocin ( $A U / m L$ )}

For the potential application of B. tequilensis ST816CD and B. subtilis ST830CD as human probiotics with antimicrobial properties, the dynamics of bacteriocin production by the two strains were evaluated at $37^{\circ} \mathrm{C}$ for $24 \mathrm{~h}$. Both strains showed a separate growth profile that reached OD levels of 1.3 and 1.0 for B. tequilensis ST816CD and B. subtilis ST830CD, respectively, during the stationary phase (Figure 2A,D). During bacterial growth of $24 \mathrm{~h}$, bacteriocin production of the two strains was recorded every three hours against previously mentioned test microorganisms. Their bacteriocin activity was observed after $3 \mathrm{~h}$ cultivation, during the early log phase of growth. Moreover, the highest levels of the bacteriocin activity were reached after 9 to $15 \mathrm{~h}$, depending on the test microorganism: $1600 \mathrm{AU} / \mathrm{mL}$ of B. tequilensis ST816CD bacteriocin against S. simulans KACC 13241 and S. auricularis KACC 13252 (Figure 2C); $1600 \mathrm{AU} / \mathrm{mL}$ of B. subtilis ST830CD bacteriocin against S. auricularis KACC 13252; and $3200 \mathrm{AU} / \mathrm{mL}$ against S. simulans KACC 13241 (Figure 2F). Over the same period, the $\mathrm{pH}$ was reduced from 6.5 to 5.6 for B. tequilensis ST816CD and 5.7 for B. subtilis ST830CD (Figure 2B,E). 

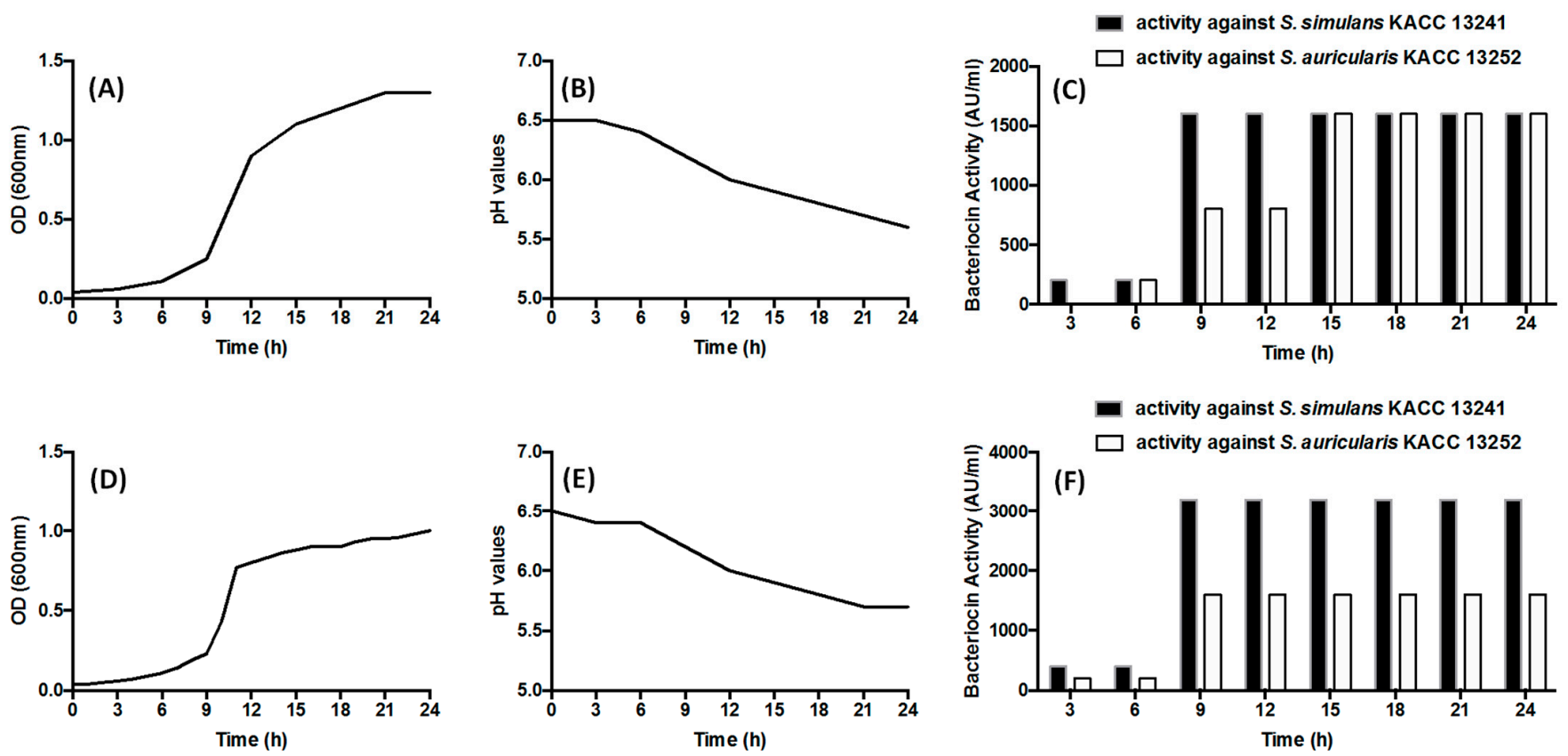

Figure 2. (A,D) Dynamics of bacterial growth (evaluated as changes in OD at $600 \mathrm{~nm}$ ), (B,E) acidification (evaluated as changes in $\mathrm{pH}$ ), and $(\mathbf{C}, \mathbf{F})$ bacteriocin production (recorded as $\mathrm{AU} / \mathrm{mL}$ ) for Bacillus tequilensis ST816CD and Bacillus subtilis ST830CD, cultured in MRS at $37^{\circ} \mathrm{C}$. The data points represent an average of three repeats for OD and $\mathrm{pH}$ that did not vary by more than $3 \%$. Standard deviation bars are not shown. Bacteriocin activity is an average of two repeats.

\subsection{The Effect of CFS on Growth and Survival of the Target Strains}

When CFS containing bacteriocins produced by the studied strains were added to actively growing cultures of the test microorganisms used in this study, bacteriostatic inhibition of the growth of the test microorganisms was observed (Figure 3). The growth of the test (indicator) microorganisms (S. similans KACC 13241 and S. auricularis KACC 13252) was inhibited in the first hours after adding the CFS of B. subtilis ST830CD, followed by a slight recovery of the test organisms at $12 \mathrm{~h}$. However, when the CFS of B. tequilensis ST816CD was studied, OD levels of S. similans KACC 13241 and S. auricularis KACC 13252 remained constant for the monitored period (Figure 3).
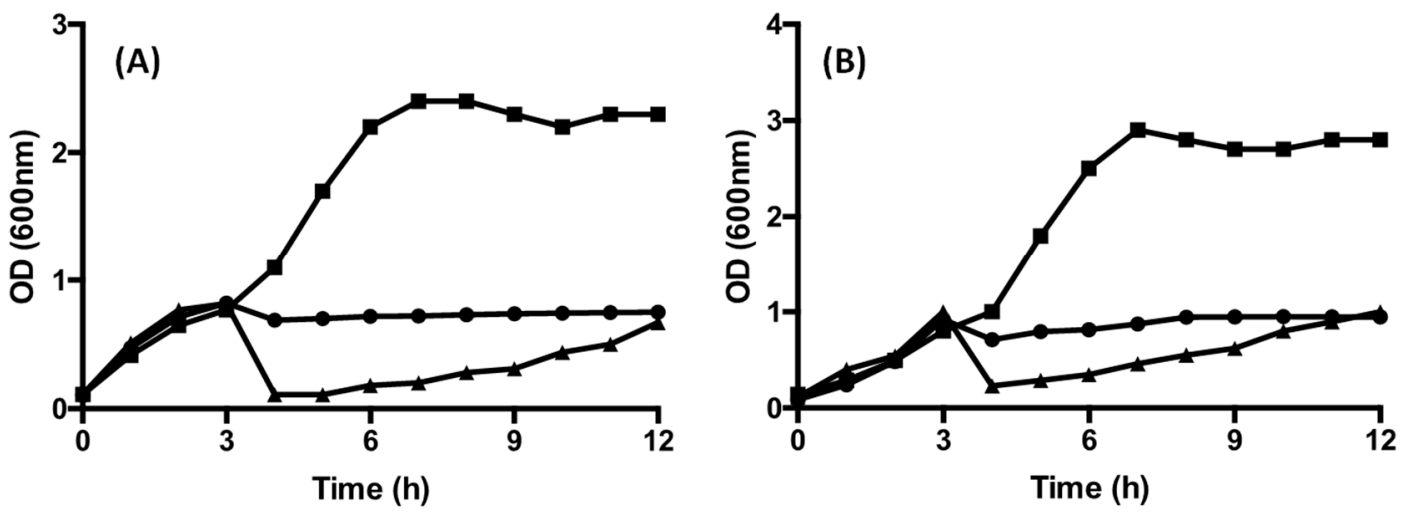

Figure 3. Activity of the Bacillus tequilensis ST816CD and Bacillus subtilis ST830CD versus (A) S. simulans KACC 13241, (B) S.

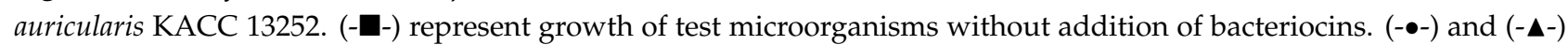
represent growth of the studied test organisms in presence of bacteriocin produced by Bacillus tequilensis ST816CD and Bacillus subtilis ST830CD. Bacteriocins were added $3 \mathrm{~h}$ after initial incubation of test organisms. The data points represent an average of two repeats and did not vary by more than $2 \%$. Standard deviation bars are not shown. 


\subsection{Adhesion Properties}

Different adsorption levels were detected for the bacteriocins produced by B. tequilensis ST816CD and B. subtilis ST830CD to food-borne pathogens and microorganisms related to the oral cavity (Table 1). However, high adsorption levels (Table 1) to the sensitive and resistant test strains used in this experimental set-up (Table 2) raises questions about how some test strains were able to resist a high level of adsorption of the studied bacteriocins or, by contrast, how others were killed at low levels. Environmental factors including different temperatures, $\mathrm{pH}$, and chemicals also affected the adsorption processes of the selected bacteriocins to the target cells (Table 1).

\subsection{Spectrum of Activity}

Bacteriocins produced by the selected strains were evaluated against the test microorganisms, including L. monocytogenes and some Staphylococcus spp. characterized as human and animal pathogens, respectively (Table 2). It was observed that the studied bacteriocins showed inhibitory activity against L. monocytogenes and several Staphylococcus strains on a strain-specific basis (Table 2), having the potential to be applied as therapeutically potent agents for the control of infections related to these pathogens.

\subsection{Presence of Genes for Antimicrobials}

To better understand the effectiveness of bacteriocins produced by B. tequilensis ST816CD and B. subtilis ST830CD, the genomic DNA of both strains was screened for the presence of different known bacteriocins associated with the genus Bacillus (Table 3). Based on the knowledge that the majority of Bacillus spp. can be producers of a variety of antimicrobials besides bacteriocins, a PCR-based analysis targeting genes related to some other antimicrobials was performed (Table 3). B. tequilensis ST816CD generated positive results for the presence of surfactin (srfa), subtilosin (sbo), and iturin (itu), while B. subtilis ST830CD showed the presence of genes associated with the production of surfactin (srfa) and subtilosin $(s b o)$.

\subsection{Safety Features}

\subsubsection{Evaluation for Presence of Virulence Genes}

In the present study, DNA obtained from B. tequilensis ST816CD and B. subtilis ST830CD was also screened for the presence of genes associated with previously described roles in the pathogenicity of specific Bacillus spp. (Table 3).

\subsubsection{Production of Biogenic Amines, Gelatinase, and Hemolytic Activity}

In addition to scanning for different genes associated with virulence potential, standard physiological approaches were applied in the evaluation of the safety of the strains with regard to the production of gelatinase, hemolytic activity, and production of biogenic amines (Table 4).

Expression of ß-hemolytic activity is considered a virulent factor and comprises one of the basic safety tests for prescreening a strain before further investigation as a potential probiotic. B. tequilensis ST816CD and B. subtilis ST830CD exhibited $\gamma$-hemolytic and $\alpha$ hemolytic activity, respectively (Table 4). Positive gelatinase activity is also frequently considered as a potential virulent factor, and therefore, no production of gelatinase is recommended for the possible application of a specific strain as a probiotic. In our study, $B$. tequilensis ST816CD generated positive results for gelatinase production, while B. subtilis ST830CD was negative (Table 4). Both strains in this study are biogenic amine producers (Table 4).

\subsubsection{Resistance/Susceptance to the Antibiotics}

B. tequilensis ST816CD and B. subtilis ST830CD were evaluated for potential levels of resistance to different antibiotics (Table 4). Based on the observed inhibition zones, both strains can be considered as safe related to the potential risk of transmission of antibiotic 
resistance determinants. Only B. tequilensis ST816CD was found to be resistant to penicillin (Table 4).

\subsection{Beneficial Properties; Screening for Some Beneficial Genes}

In our study, DNA from B. tequilensis ST816CD and B. subtilis ST830CD were estimated for the presence of different genes related to beneficial properties (Table 3). In summary, $B$. tequilensis ST816CD generated a positive result for the presence of genes encoding glutamate decarboxylase ( $g a d$ ) for $\gamma$-aminobutyric acid (GABA) production, whereas B. subtilis ST830CD showed no evidence for the presence of genes related to adhesion, production of folate, and other antimicrobials tested in this study.

\subsection{Proteolytic Activity}

Both strains, B. tequilensis ST816CD and B. subtilis ST830CD, grown on MRS plates supplemented with $10 \%$ skim milk or $5 \%$ Na-caseinate, showed the ability to hydrolyze the milk protein and casein, respectively (data not shown).

From the physiological tests, we observed that both strains can produce proteolytic enzymes, based on the visual digestion of the milk and Na-caseinate. Based on the APIZym test and interpretation of the results according to the manufacturer's manual (Table 6), both strains were found to produce alkaline phosphatase, esterase $(C 4)$, esterase Lipase (C 8), leucine arylamidase, valine arylamidase, acid phosphatase, and naphthol-AS-BIphosphohydrolase. Compared to B. tequilensis ST816CD, B. subtilis ST830CD showed a weaker ability to produce cystine arylamidase and trypsin. However, no evidence for the production of other key enzymes, included as part of the APIZym kit, was recorded (Table 6).

Table 6. Enzyme production profile of Bacillus tequilensis ST816CD and Bacillus subtilis ST830CD recorded by APIZym (BioMerieux).

\begin{tabular}{ccc}
\hline Enzyme & $\begin{array}{c}\text { B. tequilensis } \\
\text { ST816CD }\end{array}$ & $\begin{array}{c}\text { B. subtilis } \\
\text { ST830CD }\end{array}$ \\
\hline alkaline phosphatase & 3 & 3 \\
esterase (C 4) & 4 & 4 \\
esterase Lipase (C 8) & 2 & 2 \\
leucine arylamidase & 2 & 2 \\
valine arylamidase & 3 & 2 \\
cystine arylamidase & 2 & 1 \\
trypsin & 2 & 1 \\
acid phosphatase & 2 & 2 \\
naphthol-AS-BI- & 3 & 3 \\
phosphohydrolase & & \\
\hline A value ranging from 0-5 was assigned, corresponding to the colors developed: 0 -negative reaction; 1 and \\
2-intermediate positive reactions; 3, 4, or 5-positive with different levels of intensity, according to the manu- \\
facturer's recommendations (BioMerieux). Enzymes with a negative reaction $(0)$ to both strains were listed as \\
lipase (C 14), $\alpha$-chymotrypsin, $\alpha$-galactosidase, $\beta$-galactosidase, $\beta$-glucuronidase, $\alpha$-glucosidase, $\beta$-glucosidase, \\
$N$-acetyl- $\beta$-glucosaminidase, $\alpha$-mannosidase, and $\alpha$-fucosidase.
\end{tabular}

\subsection{Production of Lactic Acid}

Both experimental strains were evaluated for the production levels of lactic acid. $B$. tequilensis ST816CD and B. subtilis ST830CD were cultured in MRS for $24 \mathrm{~h}$ at $37^{\circ} \mathrm{C}$ and levels of D/L-lactic acid detected in the CFS were $0.56 / 4.37 \mathrm{~g} / \mathrm{L}$ and $0.00 / 0.00 \mathrm{~g} / \mathrm{L}$, respectively.

\subsection{Hydrophobicity}

Average values of hydrophobicity levels were recorded to be $2.5 \%$ and $1.8 \%$ for $B$. tequilensis ST816CD and B. subtilis ST830CD, respectively. 


\section{Discussion}

In our study, we screened different Korean traditional fermented food products with the purpose of isolating bacteriocinogenic strains with potential application for the control of some oral-associated pathogens. Previously, different Bacillus spp. were isolated from similar Korean fermented products, but few reports focused on the production of bacteriocins [30-32]. Based on the initial screening of 69 isolates, considered as promising candidates for bacteriocin production, after different steps of pre-selection, only two isolates were selected for future studies. Based on the identification process, strain ST816CD, isolated from radish kimchi, was identified as Bacillus tequilensis, and strain ST830CD, isolated from chili paste (gochujang), was identified as B. subtilis. Bacteriocins are ribosomally produced antimicrobial peptides [33], and proteolytic enzymes facilitate the destruction of the functional structures of these antimicrobial metabolites, thereby losing their activity. Moreover, many studies have reported that members of the genus Bacillus can produce a wide arsenal of antimicrobial metabolites, including antibiotics, enzymes, and surfactants [34].

Isolation of a bevy of B. tequilensis and B. subtilis strains from traditional fermented food products in Korea was previously reported $[35,36]$ and some were characterized as producers of bacteriocin-like inhibitory substances [37]. Nevertheless, the biological roles of B. tequilensis and B. subtilis for fermentation of kimchi and gochujang have not been clarified. Likewise, the question is whether these two strains can be considered as constant inhabitants with appropriate biological roles in these fermented food products, or whether they are evidence of cross-contamination due to low hygienic management during the preparation and fermentation processes. Are they beneficial strains with essential roles in the fermentation of these food products, or could these contaminants serve as markers of low hygienic levels during manufacture processes? Current trends around the world are to look for homemade traditional fermented products known as healthier, beneficial, and functional products. However, this trend is considered rational only if the safety and quality of these beneficial products are scientifically secured together with appropriate manufacturing practices. If a specific strain is considered safe, has beneficial properties, and survives under the technical conditions of the specific fermented products, it can be explored and eventually applied as a starter culture or as part of a food product carrying the strain as vector for delivery of beneficial microorganisms to the consumers. This may provide a possible perspective for the future.

As mentioned earlier, bacteriocins are antimicrobial polypeptides produced by the ribosomal machinery of the bacterial cells [33]. Some bacteriocins that include modified amino acids in their structure are generally classified as antibiotics [38]. Antimicrobial activity of inhibitory metabolites produced by B. tequilensis ST816CD and B. subtilis ST830CD was confirmed to be of proteinaceous nature with the presence of additional non-proteinaceous antimicrobial agent, as shown later in this study, and associated with the presence of genes encoding the production of surfactants. Moreover, bacteriocins produced by B. tequilensis ST816CD and B. subtilis ST830CD showed stability when exposed to varying temperatures, chemicals, and levels of $\mathrm{pH}$ (Table 5). Such results were expected, since most bacteriocins are heat-stable, related to the fact that they are small antimicrobial peptides, specially belonging to Class I and II (less than $10 \mathrm{kDa}$ ) [10].

Even if it is generally established that bacterial growth is clearly dependent on the incubation temperature, the expression of genes encoding the production of antimicrobial metabolites is even more sensitive to temperatures fluctuation [39]. From an industrial point of view, the determination of optimal growth temperature is a critical point, closely related to, e.g., the cost of production, control of possible contamination, and specificity of the design of production facilities. From the perspective of the potential application of a bacteriocinogenic strain as a starter culture, optimal bacteriocin production needs to follow the specificity of the fermentation process and future storage of (food) products. Both strains showed a specific growth profile, as well as acidification and levels of bacteriocin production (Figure 2). A major merit of Bacillus spp. is that they are generally (exception 
Bacillus coagulans) not strong acid producers ( $\mathrm{pH} 4.0-5.0$ ) as compared to most LAB. Acidification of the environment can contribute to anti-pathogenic properties of the bacteria in some fermented food products, but also result in undesired effects such as nonspecific inhibition of the growth of other beneficial microorganisms.

Previous reports on the production of bacteriocins from different Bacillus strains mentioned levels of bacteriocin activity similar to those in the present study. Yang and Chang [37] reported that B. subtilis MJP1 isolated from meju, Korean dried fermented soybeans, was able to produce bacteriocin levels of $3200 \mathrm{AU} / \mathrm{mL}$ and $1600 \mathrm{AU} / \mathrm{mL}$, respectively, active against fungi and bacteria. In addition, Park et al. [36] reported that B. tequilensis JBC17126 isolated from Korean soybean pastes exerted antibacterial activity against food pathogens such as B. cereus KACC 13064 and S. aureus KACC 1927.

The role of bacteriocins in inhibitory processes can be defined as either bactericidal or bacteriostatic based on whether they kill or inhibit sensitive strains [40]. Both studied bacteriocins were evaluated as bacteriostatic, based on the observed inhibition of the growth of the test microorganisms (Figure 3). The growth of the test microorganisms was inhibited in the first few hours after adding the CFS of B. subtilis ST830CD. Salum et al. [41] reported that a bacteriocin produced by B. subtilis W42 isolated from cheonggukjang showed a high level of bactericidal activity against various Gram-positive food spoilage and pathogenic bacteria, including L. monocytogenes ATCC 19111. In addition, an antibacterial agent produced by B. tequilensis MSI45 of marine origin was able to suppress the growth of multi-drug resistant Staphylococcus aureus [42]. Modes of action of bacteriocins depend on the specific nature of the expressed antimicrobial and sensitivity of the applied test microorganisms. It cannot be expected that one specific bacteriocin can act as a panacea and solve all the problems with human- and veterinary-related pathogenic or food spoilage microorganisms. Each bacteriocin has its inhibitory specificity, especially to closely related bacteria. Numerous reports suggest that the application of bacteriocins as alternative antimicrobials or adjunct antimicrobial agents can be a promising solution for reducing the antibiotic resistance of undesired bacteria $[33,43]$. Moreover, building a multitude of bacteriocins that are customized or bioengineered will maximize the potential of synergy effects. Even though a few bacteriocins have been used as food preservatives or therapeutic agents in clinical settings, there are still insufficient data on the safety and toxicity of such bacteriocins.

The primary part of the mode of action is the adsorption of the bacteriocin to the specific receptors on the membrane surface of Gram-positive target cells. After the target is recognized, a bactericidal mode of action develops in the cell membrane. Class I bacteriocins interact with lipid II in the cell membrane and then either perforate the membrane or inhibit murein synthesis, whereas class II bacteriocin interact with Man-PTS or static electricity and then cut a hole [44]. Moreover, evaluation of the correlation of environmental conditions with adsorption of bacteriocins to the cell surface of the target cells was conducted to predict the effectiveness of bacteriocins under various conditions. Previously, Pingitore et al. [45] showed that different testing conditions such as various $\mathrm{pH}$ values, a wide temperature range, and the presence of salts and surfactants interfered with the adsorption of bacteriocins produced by two bacteriocinogenic strains of Enterococcus mundtii CRL35 and Enterococcus faecium ST88Ch to some pathogenic and non-pathogenic microorganisms such as L. monocytogenes and Lactobacillus sakei. Based on the results, they predicted the optimal adsorption level according to the effectiveness of those strains as biopreservatives in cheese-making. The results were confirmed by in situ evaluation of both mentioned bacteriocinogenic strains against $L$. monocytogenes, which resulted in different levels of control of L. monocytogenes during cheese-making under different conditions.

The bacteriocins produced by B. tequilensis ST816CD and B. subtilis ST830CD showed different adsorption levels to food-borne pathogens and microorganisms associated with the oral cavity (Table 1). As previously mentioned, this information can be used as a basis for possible prediction of the efficacy of these bacteriocins in their application either as 
effective antimicrobial agents during specific fermentation processes or as bio-therapeutic agents in clinical settings and/or for bio-preservation.

Normally, bacteriocins are antimicrobial peptides with a narrow spectrum of activity with specific advantages compared to antibiotics [33]. Therapeutic application of antibiotics can lead to the removal of the targeted organisms as well as commensal organisms, thereby causing side effects such as destruction of GIT microbiota even after a short-term period of antibiotic administration [46]. An advantage of bacteriocins could be the specific targeting of only causative pathogens, thereby preventing cross-resistance in non-targeted pathogens, and reducing incidental damage of the host microbiome [47].

The bacteriocins produced by the selected strains were investigated for their effects against selected test microorganisms, including L. monocytogenes and some Staphylococcus spp., characterized as human and animal pathogens, and against different food-related spoilage organisms (Table 2). The results showed their potential for application as potent therapeutic agents for the control of infections/spoilage related to these pathogens. Barboza-Corona et al. [48] suggested the potential of bacteriocins produced by B. thuringiensis for the control of mastitis in dairy cows, also referring to their activity against multiresistant $S$. aureus strains.

In order to better understand the effectiveness of the bacteriocins produced by $B$. tequilensis ST816CD and B. subtilis ST830CD, the genomic DNA of both strains was screened for the presence of different known bacteriocin genes associated with the genus Bacillus (Table 3). It was previously shown that a strain of B. subtilis produces subtilosin A, a ribosomally-synthesized and anionic bacteriocin, as well as a non-ribosomally synthesized lipopeptide, surfactin (srfa), also including different antimicrobials, belonging to the iturin (itu) family [49]. The presence of genes associated with the production of bacteriocins and other antimicrobials in the total DNA of the two studied Bacillus strains supported results observed in their spectrum of activity. A previous study [50] suggested that a broad spectrum of antimicrobial activity can be based on the accumulation of bacteriocinogenic (subtilosin A1) and hemolytic activities. Furthermore, surfactin from B. subtilis interrupted biofilm formation of individual and mixed cultures of food-borne pathogenic bacteria such as S. aureus and L. monocytogenes [51]. A biosurfactant from B. tequilensis SDS21 was suggested for application as a disinfectant by exhibiting bactericidal and biofilm dislodging activity [52]. The presence of genes associated with the production of surfactant (surfactin) can be explained by the partial reduction only of the antimicrobial activity of CFS obtained from both Bacillus strains after treatment with proteolytic enzymes (Tables 3 and 5).

Bacillus spp. are a highly diverse group of bacteria and include representatives of typical pathogens such as $B$. cereus and even of potential biological weapons such as $B$. anthracis [53]. On the other side, from a beneficial point of view, safe strains with long applications in food fermentation processes and, more recently, in different biotechnological processes [8] have extensively been studied in recent decades. Thus, characterization of the safety properties of potentially beneficial Bacillus candidates should be mandatory before practical application.

In the present study, DNA obtained from B. tequilensis ST816CD and B. subtilis ST830CD was also screened for the presence of genes related to previously described roles in the pathogenicity of specific Bacillus spp. (Table 3). According to Guinebretiere et al. [25], the presence of the three genes $(h b l \mathrm{~A}, h b l \mathrm{~B}$, and $h b l \mathrm{C}$ for expression of hemolysin $\mathrm{BL}$ ) or the three genes (nhe $\mathrm{A}, n h e \mathrm{~B}$, and $n h e \mathrm{C}$ for expression of non-hemolytic enterotoxin) needed to be determined in view of potential virulence effects. However, these were not detected (Table 3), thereby asserting that the studied strains might be considered as safe.

Standard physiological approaches were applied in the evaluation of the safety of the studied strains and included the production of gelatinase, hemolytic activity, and production of biogenic amines (Table 4). B. tequilensis ST816CD and B. subtilis ST830CD exhibited $\gamma$-hemolytic and $\alpha$-hemolytic activity, respectively (Table 4 ). Other studies reported B. tequilensis YC5-2 from the gut of wild adult shrimp [54] and B. tequilensis FR9 from GIT of free-range chicken [55] as $\gamma$-hemolytic. 
Gelatinase activity is frequently considered as a virulence factor; the absence of this property is recommended for strains intended as probiotics. However, gelatinase production can be a beneficial characteristic in some biotechnological or food preparation processes, where the liquefaction of gel-like structures may be a positive feature [56]. Both strains in our study produced gelatinase.

Production of biogenic amines is a natural process typically resulting from the decarboxylation of amino acids and is generally considered as a negative feature for the probiotic and starter culture strains in the food industry. The intake of excessive amounts of biogenic amines beyond the allowable threshold can have negative health consequences, including elevated blood sugar and blood pressure levels of humans and animals [57]. Tyrosine, ornithine, lysine, and histidine, as precursors of the most important biogenic amines in foods, were tested in this study. Although some legislative organs refer to threshold values for biogenic amines in specific products (e.g., maximum limits for histamine in fish), each country has its own specific regulations on "tolerance" levels for biogenic amines in various food products [58]. Both strains in this study were capable of producing biogenic amines (Table 4).

B. tequilensis ST816CD and B. subtilis ST830CD were evaluated for potential levels of resistance to different antibiotics (Table 4). Resistance of beneficial strains to antibiotics is a controversial subject. On the one side, some authors defend the hypothesis that probiotics and other beneficial strains should be susceptible to antibiotics. If any antibiotic resistance genes are present on the genome of beneficial strains, those genes can be horizontally transferred via biofilm or other mechanisms to other microbiota and thereby result in the spread of antibiotic resistance [59]. Moreover, Teuber [60] and Salyers et al. [61] suggested that starter cultures or probiotics may serve as vectors in the transfer of antibiotic-resistant genes.

On the other side, the question is how actively horizontal gene transfer occurs in the GIT of the host. Suvorov [62] hypothesized a relatively low level for such a process. It might be important to focus on the likelihood of the potential risk of the process by examining the presence of resistant genes located on bacterial chromosomes or easily transmittable genetic determinants such as plasmids and transposon and adhesion levels of the antibiotic-resistant strains. Dispersion of antibiotic resistance genes between strains should be considered an important priority in safety assessment.

Nonetheless, moderate antibiotic resistance can be regarded as a positive feature in specific cases. Probiotics may need to be applied parallel to other medicaments including antibiotics. If the applied probiotics are fully susceptible to antibiotics, their survival potential will be hampered and their potency lost. Therefore, moderate resistance of probiotic cultures to antibiotics may result in synergy effects to the host during treatment and restoration. However, the likelihood of transfer of antibiotic resistance determinants from probiotic bacteria to potential food or gut pathogens should not be overestimated [63].

Screening for the presence of genes related to specific beneficial properties has become routine concerning the development of biomolecular techniques in the past 30 years. In our study, DNA from B. tequilensis ST816CD and B. subtilis ST830CD was studied for the presence of different genes associated with beneficial properties (Table 3). In summary, genes encoding glutamate decarboxylase $(\mathrm{gad})$ for $\gamma$-aminobutyric acid (GABA) production were detected in $B$. tequilensis ST816CD, whereas no evidence for the presence of genes related to adhesion, production of folate, and other antimicrobials tested in this study were found in B. subtilis ST830CD. GABA is a non-proteinaceous amino acid, also known as an inhibitory neurotransmitter, and has diverse biological functions such as fosterage of the metabolism of brain cells, regulation of secretion of growth hormone, decrease in blood pressure, pain/anxiety relief, and treatment of many diseases [64,65]. Previous studies reported that Bacillus strains, mostly of B. subtilis, isolated from milk, kefir, and rice straw were also capable of producing GABA [66,67].

Production of proteolytic enzymes can be considered as either a beneficial or virulence factor regarding the type of the expressed proteases and the subject of their activity. 
Production of proteases is a rare case for strains characterized as bacteriocin producers. It was reported that for some bacteriocinogenic strains, the reduction in recorded bacteriocins after the stationary phase might result from an increase in the number of dead/lysed cells and liberation of some intracellular proteases. Some authors classified the production of proteolytic enzymes as a virulence factor since increased levels of proteases can induce negative interactions with the gut lumen and proteins of beneficial bacterial strain [68]. On the other hand, however, the right kind of proteolytic enzymes produced in the right concentration and at the right time can have a beneficial role, particularly for industrial applications. Beneficial strains able to produce proteolytic enzymes play an essential role as starter cultures in the meat industry [69]. Such proteolytic enzymes can also contribute to the reduction in allergenicity in dairy products by enzymatic digestion of the caseins [70], and also in other industries involving bakery [71], brewing [72], food additives [73], and feed production [74].

Both strains, B. tequilensis ST816CD and B. subtilis ST830CD, grown on MRS agar supplemented with $10 \%$ skim milk or $5 \%$ Na-caseinate, showed the ability to hydrolyze the milk protein and casein, respectively. Such characteristics justify future investigations to explore their properties and potential application as starter cultures with the ability to reduce the casein as a cause of allergenicity.

In our study, we observed that both strains can produce proteolytic enzymes, based on the visual digestion of milk and Na-caseinate. Moreover, based on the performed APIZym test and interpretation of the results according to the manufacturer's manual, both strains can be considered as producers of different enzymes (Table 6) in a strain-specific manner. Production of different enzymes does not only play a fundamental role in the adaptive ability of bacterial strains to specific environmental conditions, but can also serve as property for specific applications. Previously, Park et al. [75] suggested that lipolytic properties of some Bacillus strains can serve as selection criteria for probiotic strains with anti-obesity properties. Montel et al. [76] discussed the role of different enzymes, expressed by different starter cultures, in the formation of the aroma/organoleptic profile of fermented food products. El Mecherfi et al. [77] evaluated the role of beneficial organisms in the reduction of gluten resulting from specific proteolytic activity of starter cultures. Biscola et al. [78] studied the role of proteolytic enzymes produced by some LAB in the reduction of the allergenicity of dairy products. The recorded specific proteolytic acidity, in addition to other enzymatic activities expressed by both studied strains, merit additional attention and their more specific evaluation as potential beneficial feature of these bacterial cultures.

As expected, very low levels of lactic acid were recorded in connection with the previously observed drop of $\mathrm{pH}$ levels to 5.6 and 5.7 recorded after $24 \mathrm{~h}$ cultivation of the strains. Production of lactic acid may contribute to the beneficial effects of probiotics since by enforcing their antimicrobial potential. However, high levels of lactic acid may have negative effects in applications of strains in the oral cavity where high acidity may accelerate dental problems as a consequence of the interaction between lactic acid and tooth enamel [79]. Moreover, bacterial cultures can produce both the $\mathrm{L}(+)$ and $\mathrm{D}(-)$ isomers of lactic acid. This characteristic is typical of each bacterial species and a key feature in biochemical bacterial taxonomy according to Bergey's Manual of Systematic Bacteriology [18]. Production of $\mathrm{D}(-)-$ lactic acid is considered an undesirable feature because high levels of D-lactic acid can cause acidosis, a potential adverse effect, especially in babies and infants [80].

Low hydrophobicity levels of $2.5 \%$ and $1.8 \%$ were recorded for B. tequilensis ST $816 \mathrm{CD}$ and B. subtilis ST830CD, respectively. Cell surface hydrophobicity reflects the specificity of the cell surface composition and presents a possible non-specific interaction between microbial cells and host cells. It is believed that high hydrophobicity levels may enable stronger adhesion of bacterial cells to mucosal cells [81]. Todorov et al. [82] reported a high level of hydrophobicity of about $80 \%$ for some LAB strains (Lactobacillus rhamnosus and Lb. plantarum) compared to a 55\% hydrophobicity level for Lb. rhamnosus GG. De Wouters et al. [83] reported a proportional correlation between hydrophobicity and adherence to a Caco-2 cell line through negative zeta potential. Even though hydrophobicity may assist in 
bacterial adhesion, it is not a prerequisite for strong adherence to intestinal cells. The level of hydrophobicity varies among genetically related species and even among strains of the same species [84].

\section{Conclusions}

Two Bacillus strains isolated from Korean traditional fermented food products, $B$. tequilensis ST816CD and B. subtilis ST830CD, demonstrated antibacterial activity against clinical- and food-associated pathogens. However, since their overall safety could not be confirmed, their potential for application as probiotic strains may be questioned, despite meeting several criteria. This study clearly showed that in the selection of beneficial strains, apart from probiotic properties, special attention needs to be given to the safety features of the studied strains. Nevertheless, their bacteriocins with specific beneficial characteristics may find applications as purified metabolites in numerous fields such as in food preservation, medicine, and in the dairy and pharmaceutical industries.

Author Contributions: Conceptualization, S.D.T.; experimental work, G.H.C., J.I.I.F., C.M.D., J.E.V.B. and S.D.T.; data analysis, S.D.T.; funding, S.D.T. and W.H.H.; writing—original draft, S.D.T.; writing-review and editing, J.I.I.F., C.M.D., S.D.T. and W.H.H. All authors have read and agreed to the published version of the manuscript.

Funding: Research and publication fees were covered by a grant from the National Research Foundation (NRF) funded by the Ministry of Science and ICT (NRF-2018M3A9F3021964), Seoul, Korea.

Institutional Review Board Statement: Not applicable.

Informed Consent Statement: Not applicable.

Data Availability Statement: All data generated or analyzed during this study are included in this published article and comply with research standards.

Acknowledgments: The authors acknowledge Mia Miau for her unconditional support.

Conflicts of Interest: The authors declare no conflict of interest.

\section{References}

1. Nicholson, W.L. Roles of Bacillus endospores in the environment. Cell Mol. Life Sci. 2002, 59, 410-416. [CrossRef] [PubMed]

2. Claus, D.; Berkeley, R.C.W. Genus Bacillus. In Bergey's Manual of Systematic Bacteriology; Sneath, P.H.A., Mair, N.S., Sharpe, M.E., Holt, J.G., Eds.; The Williams \& Wilkins Co.: Baltimore, MD, USA, 1986; Volume 2, pp. 1105-1139.

3. Su, Y.; Liu, C.; Fang, H.; Zhang, D. Bacillus subtilis: A universal cell factory for industry, agriculture, biomaterials and medicine. Microb. Cell Fact. 2020, 19, 173. [CrossRef] [PubMed]

4. Oguntoyinbo, F.A.; Sanni, A.I.; Franz, C.M.; Holzapfel, W.H. In vitro fermentation studies for selection and evaluation of Bacillus strains as starter cultures for the production of okpehe, a traditional African fermented condiment. Int. J. Food Microbiol. 2007, 113, 208-218. [CrossRef] [PubMed]

5. Kubo, Y.; Rooney, A.P.; Tsukakoshi, Y.; Nakagawa, R.; Hasegawa, H.; Kimura, K. Phylogenetic analysis of Bacillus subtilis strains applicable to natto (fermented soybean) production. Appl. Environ. Microbiol. 2011, 77, 6463-6469. [CrossRef] [PubMed]

6. Chettri, R.; Tamang, J.P. Bacillus species isolated from Tungrymbai and Bekang, naturally fermented soybean foods of India. Int. J. Food Microbiol. 2015, 197, 72-76. [CrossRef]

7. Compaoré, C.S.; Nielsen, D.S.; Ouoba, L.I.I.; Berner, T.S.; Nielsen, K.F.; Sawadogo, H.; Diawara, B.; Ouédraogo, G.A.; Jakobsen, M.; Thorsen, L. Co-production of surfactin and a novel bacteriocin by Bacillus subtilis subsp. subtilis H4 isolated from Bikalga, an African alkaline hibiscus sabdari, a seed fermented condiment. Int. J. Food Microbiol. 2013, 162, 297-307. [CrossRef]

8. Todorov, S.D.; Ivanova, I.V.; Popov, I.; Weeks, R.; Chikindas, M.L. Bacillus spore-forming probiotics: Benefits with concerns? Crit. Revi. Microbiol 2021, in press. [CrossRef]

9. Santos, R.A.; Oliva-Teles, A.; Pousão-Ferreira, P.; Jerusik, R.; Saavedra, M.J.; Enes, P.; Serra, C.R. Isolation and characterization of fish-gut Bacillus spp. as source of natural antimicrobial compounds to fight aquaculture bacterial diseases. Marine Biotechnol. 2021, 23, 276-293. [CrossRef]

10. Abriouel, H.; Franz, C.M.; Ben Omar, N.; Galvez, A. Diversity and applications of Bacillus bacteriocins. FEMS Microbiol. Rev. 2011, 35, 201-232. [CrossRef]

11. Hong, H.A.; Duc, L.H.; Cutting, S.M. The use of bacterial spore formers as probiotics. FEMS Microbiol. Rev. 2005, 29, 813-835. [CrossRef]

12. Lodemann, U.; Lorenz, B.M.; Weyrauch, K.D.; Martens, H. Effects of Bacillus cereus var. toyoi as probiotic feed supplement on intestinal transport and barrier function in piglets. Arch. Anim. Nutr. 2008, 62, 87-106. [CrossRef] [PubMed] 
13. Stenfors, A.L.P.; Fagerlund, A.; Granum, P.E. From soil to gut: Bacillus cereus and its food poisoning toxins. FEMS Microbiol. Rev. 2008, 32, 579-606. [CrossRef] [PubMed]

14. Haydushka, I.A.; Markova, N.; Kirina, V.; Atanassova, M. Recurrent Sepsis due to Bacillus licheniformis. J. Glob. Inf. Dis. 2012, 4, 82-83. [CrossRef] [PubMed]

15. Lagos, R. Bacteriocins. In Brenner's Encyclopedia of Genetics, 2nd ed.; Elsevier Inc.: Amsterdam, The Netherlands, 2013; pp. 277-279. [CrossRef]

16. Zacharof, M.P.; Lovitt, R.W. Bacteriocins Produced by Lactic Acid Bacteria. A review article. APCBEE Procedia 2012, 2, 50-56. [CrossRef]

17. Begley, M.; Cotter, P.D.; Hill, C.; Ross, R.P. Identification of a novel two-peptide lantibiotic, lichenicidin, following rational genome mining for LanM proteins. Appl. Environ. Microb. 2009, 75, 5451-5460. [CrossRef]

18. De Vos, P.; Garrity, G.M.; Jones, D.; Kreig, N.R.; Ludwig, W.; Rainey, F.A.; Schleifel, K.-H.; Whitman, W.B. Bergey's manual of systematic bacteriology. In The Firmicutes, 2nd ed.; Springer: Dordrecht, The Netherlands, 2009; Volume 3.

19. Dos Santos, K.M.O.; de Matos, C.R.; Salles, H.O.; Franco, B.D.G.M.; Arellano, K.; Holzapfel, W.H.; Todorov, S.D. Exploring beneficial/virulence properties of two dairy-related strains of Streptococcus infantarius subsp. infantarius. Probiotics Antimicrob. Proteins 2020, 12, 1524-1541. [CrossRef]

20. Todorov, S.D.; Dicks, L.M.T. Characterization of bacteriocins produced by lactic acid bacteria isolated from spoiled black olives. J. Basic Microbiol. 2005, 45, 312-322. [CrossRef]

21. De Moraes, G.M.D.; de Abreu, L.R.; do Egito, A.S.; Salles, H.O.; da Silva, L.M.F.; Nero, L.A.; Todorov, S.D.; dos Santos, K.M.O. Functional properties of Lactobacillus mucosae strains isolated from Brazilian goat milk. Probiotics Antimicrob. Proteins 2016, 9 , 235-245. [CrossRef]

22. Todorov, S.D.; Dicks, L.M.T. Screening for bacteriocin-producing lactic acid bacteria from boza, a traditional cereal beverage from Bulgaria. Comparison of the bacteriocins. Proc. Biochem. 2006, 41, 11-19. [CrossRef]

23. Todorov, S.D.; Stojanovski, S.; Iliev, I.; Moncheva, P.; Nero, L.A.; Ivanova, I.V. Technology and safety assessment for lactic acid bacteria isolated from traditional Bulgarian fermented meat product "Lukanka". Braz. J. Microbiol. 2017, 48, 576-586. [CrossRef]

24. Chopra, L.; Singh, G.; Choudhary, V.; Sahoo, D.K. Sonorensin: An antimicrobial peptide, belonging to the heterocycloantharicin subfamily of bacteriocins, from a new marine isolate, Bacillus sonorensis MT93. Appl. Environ. Microbiol. 2014, 80, 2981-2990. [CrossRef]

25. Guinebretière, M.H.; Broussolle, V.; Nguyen-The, C. Enterotoxigenic profile of food-poisoning and foodborne Bacillus cereus strains. J. Clin. Microbiol. 2002, 40, 3053-3056. [CrossRef] [PubMed]

26. Valledor, S.J.D.; Vazquez Bucheli, J.E.; Holzapfel, W.H.; Todorov, S.D. Exploring beneficial properties of the bacteriocinogenic Enterococcus faecium ST10Bz strain isolated from boza, a Bulgarian cereal-based beverage. Microorganisms 2020, 8, 1474. [CrossRef] [PubMed]

27. Irorita Fugaban, J.I.; Vazquez Bucheli, J.E.; Holzapfel, W.H.; Todorov, S.D. Bacteriocinogenic Bacillus spp. isolated from Korean fermented cabbage (Kimchi)—Beneficial or hazardous? Fermentation 2021, 7, 56. [CrossRef]

28. Charteris, W.P.; Kelly, P.M.; Morelli, L.; Collins, J.K. Gradient diffusion antibiotic susceptibility testing of potentially probiotic Lactobacilli. J. Food. Prot. 2001, 64, 2007-2014. [CrossRef]

29. Doyle, R.J.; Rosenberg, M. Measurement of microbial adhesion to hydrophobic substrates. Meth. Enzymol. 1995, $253,542-550$.

30. Savadogo, A.; Tapi, A.; Chollet, M.; Wathelet, B.; Traoré, A.S.; Jacques, P. Identification of surfactin producing strains in Soumbala and Bikalga fermented condiments using Polymerase Chain Reaction and Matrix Assisted Laser Desorption/Ionization-Mass Spectrometry methods. Int. J. Food Microbiol. 2011, 151, 299-306. [CrossRef]

31. Sarkar, P.K.; Hasenack, B.; Nout, M.J. Diversity and functionality of Bacillus and related genera isolated from spontaneously fermented soybeans (Indian Kinema) and locust beans (African Soumbala). Int. J. Food Microbiol. 2002, 77, 175-186. [CrossRef]

32. Jung, S.; Woo, C.; Fugaban, J.I.I.; Bucheli, J.E.V.; Holzapfel, W.H.; Todorov, S.D. Bacteriocinogenic potential of Bacillus amyloliquefaciens isolated from Kimchi, a traditional Korean fermented cabbage. Probiotics Antimicrob. Proteins 2021, 13, $1195-1212$. [CrossRef]

33. Chikindas, M.L.; Weeks, R.M.; Drider, D.; Chistyakov, V.A.; Dicks, L.M.T. Functions and emerging applications of bacteriocins. Curr. Opin. Biotechnol. 2018, 49, 23-28. [CrossRef]

34. Latorre, J.D.; Hernandez-Velasco, X.; Wolfenden, R.E.; Vicente, J.L.; Wolfender, A.D.; Menconi, A.; Bielke, L.R.; Hargis, B.M.; Tellez, G. Evaluation and selection of Bacillus species based on enzyme production, antimicrobial activity, and biofilm synthesis as direct-fed microbial candidates for poultry. Front. Vet. Sci. 2016, 3, 95. [CrossRef] [PubMed]

35. Kang, S.M.; Lee, C.S.; Yoo, C.K.; Seo, W.S. Purification and characterization of fibrinolytic enzyme excreted by Bacillus subtilis K-54 isolated from Chung Guk Jang. Korean J. Appl. Microbiol. Biotechnol. 1998, 26, 507-515.

36. Park, H.J.; Oh, H.H.; Jeong, D.Y.; Kim, Y.S. Probiotic characteristics of Bacillus tequilensis JBC17126 isolated from Korean traditional soybean paste. J. Kor. Soc. Food Sci. Nutr. 2019, 48, 710-717. [CrossRef]

37. Yang, E.J.; Chang, H.C. Characterization of bacteriocin-like substances produced by Bacillus subtilis MJP1. Kor. J. Microbiol. Biotechnol. 2007, 35, 339-346.

38. Jack, R.W.; Tagg, J.R.; Ray, B. Bacteriocins of gram-positive bacteria. Microbiol. Mol. Biol. Rev. 1995, 59, 171-200. [CrossRef] 
39. Kuniyoshi, T.M.; Mendonça, C.M.N.; Vieira, V.B.; Robl, D.; Franco, B.D.G.M.; Todorov, S.D.; Tomé, E.; O'Connor, P.M.; Converti, A.; Araujo, W.L.; et al. Pediocin PA-1 production by Pediococcus pentosaceus ET34 using non-detoxified hemicellulose hydrolysate obtained from hydrothermal pretreatment of sugarcane bagasse. Bioresour. Technol. 2021, 338, 125565. [CrossRef] [PubMed]

40. Pankey, G.A.; Sabath, L.D. Clinical relevance of bacteriostatic versus bactericidal mechanisms of action in the treatment of Gram-positive bacterial infections. Clin. Infect. Dis. 2004, 38, 864-870. [CrossRef]

41. Salum, K.; Lee, H.A.; Kim, J.H. Properties of Bac W42, a bacteriocin produced by Bacillus subtilis W42 isolated from cheonggukjang. J. Microbiol. Biotechnol. 2012, 22, 1092-1100. [CrossRef]

42. Kiran, G.S.; Priyadharsini, S.; Sajayan, A.; Ravindran, A.; Selvin, J. An antibiotic agent pyrrolo[1,2-a]pyrazine-1,4-dione,hexahydro isolated from a marine bacteria Bacillus tequilensis MSI45 effectively controls multi-drug resistant Staphylococcus aureus. RSC Adv. 2018, 8, 17837-17846. [CrossRef]

43. Soltani, S.; Hammami, R.; Cotter, P.D.; Rebuffat, S.; Said, L.B.; Gaudreau, H.; Bédard, F.; Biron, E.; Drider, D.; Fliss, I. Bacteriocins as a new generation of antimicrobials: Toxicity aspects and regulations. FEMS Microbiol. Rev. 2021, 45, 039. [CrossRef]

44. Hammami, R.; Fernandez, B.; Lacroix, C.; Fliss, I. Anti-infective properties of bacteriocins: An update. Cell. Mol. Life Sci. 2013, 70, 2947-2967. [CrossRef] [PubMed]

45. Pingitore, E.V.; Todorov, S.D.; Sesma, F.; Franco, B.D.G.M. Application of bacteriocinogenic Enterococcus mundtii CRL35 and Enterococcus faecium ST88Ch in the control of Listeria monocytogenesin fresh Minas cheese. Food Microbiol. 2012, 32, 38-47. [CrossRef] [PubMed]

46. Jernberg, C.; Löfmark, S.; Edlund, C.; Jansson, J.K. Long-term ecological impacts of antibiotic administration on the human intestinal microbiota. ISME J. 2007, 1, 56-66. [CrossRef]

47. Melander, R.J.; Zurawski, D.V.; Melander, C. Narrow-spectrum antibacterial agents. Medchemcomm 2018, 9, 12-21. [CrossRef] [PubMed]

48. Barboza-Corona, J.E.; de la Fuente-Salcido, N.; Alva-Murillo, N.; Ochoa-Zarzosa, A.; Lopez-Meza, J.E. Activity of bacteriocins synthesized by Bacillus thuringiensis against Staphylococcus aureus isolates associated to bovine mastitis. Vet. Microbiol. 2009, 138, 179-183. [CrossRef] [PubMed]

49. Inès, M.; Dhouha, G. Lipopeptide surfactants: Production, recovery and pore forming capacity. Peptides 2015, 71, 100-112. [CrossRef]

50. Huang, T.; Geng, H.; Miyyapuram, V.R.; Sit, C.S.; Vederas, J.C.; Nakano, M.M. Isolation of a variant of subtilosin A with hemolytic activity. J. Bacteriol. 2009, 191, 5690-5696. [CrossRef]

51. Gomes, M.Z.V.; Nitschke, M. Evaluation of rhamnolipid and surfactin to reduce the adhesion and remove biofilms of individual and mixed cultures of food pathogenic bacteria. Food Control 2012, 25, 441-447. [CrossRef]

52. Singh, A.K.; Sharma, P. Disinfectant-like activity of lipopeptide biosurfactant produced by Bacillus tequilensis strain SDS21. Coll. Surf. B Biointerfaces 2020, 185, 110514. [CrossRef]

53. Ehling-Schulz, M.; Lereclus, D.; Koehler, T.M. The Bacillus cereus group: Bacillus species with pathogenic potential. Microbiol. Spectr. 2019, 7, 10. [CrossRef]

54. Luis-Villaseñor, I.E.; Macías-Rodríguez, M.E.; Gómez-Gil, B.; Ascencio-Valle, F.; Campa-Córdova, Á.I. Beneficial effects of four Bacillus strains on the larval cultivation of Litopenaeus vannamei. Aquaculture 2011, 321, 136-144. [CrossRef]

55. Rani, R.P.; Anandharaj, M.; Hema, S.; Deepika, R.; Ravindran, A.D. Purification of antilisterial peptide (Subtilosin A) from novel Bacillus tequilensis FR9 and demonstrate their pathogen invasion protection ability using human carcinoma cell line. Front Microbiol. 2016, 7, 1910. [CrossRef]

56. Hisano, T.; Abe, S.; Wakashiro, M.; Kimura, A.; Murata, K. Isolation and properties of a collagenase with caseinolytic activity from a Pseudomonas sp. J. Ferm. Bioeng. 1989, 68, 399-403. [CrossRef]

57. Shalaby, A.R. Significance of biogenic amines to food safety and human health. Food Res. Int. 1996, 29, 675-690. [CrossRef]

58. Spano, G.; Russo, P.; Lonvaud-Funel, A.; Lucas, P.; Alexandre, H.; Grandvalet, C.; Coton, E.; Coton, M.; Barnavon, L.; Bach, B.; et al. Biogenic amines in fermented foods. Eur. J. Clin. Nutr. 2010, 64, 95-100. [CrossRef] [PubMed]

59. Stalder, T.; Top, E. Plasmid transfer in biofilms: A perspective on limitations and opportunities. NPJ Biofilms Microbiomes 2016, 2, 16022. [CrossRef]

60. Teuber, M. Spread of antibiotic resistance with food-borne pathogens. Cell. Mol. Life Sci. 1999, 56, 755-763. [CrossRef]

61. Salyers, A.A.; Gupta, A.; Wang, Y. Human intestinal bacteria as reservoirs for antibiotic resistance genes. Trends Microbiol. 2004, 12, 412-416. [CrossRef] [PubMed]

62. Suvorov, A. What Is Wrong with Enterococcal Probiotics? Probiotics Antimicrob. Proteins 2020, 12, 1-4. [CrossRef]

63. Gueimonde, M.; Sánchez, B.; de los Reyes-Gavilán, C.; Margolles, A. Antibiotic resistance in probiotic bacteria. Front. Microbiol. 2013, 4, 202. [CrossRef] [PubMed]

64. Powers, M.E.; Yarrow, J.F.; McCoy, S.C.; Borst, S.E. Growth hormone isoform responses to GABA ingestion at rest and after exercise. Med. Sci. Sports Exerc. 2008, 40, 104-110. [CrossRef]

65. Diana, M.; Quílez, J.; Rafecas, M. Gamma-aminobutyric acid as a bioactive compound in foods: A review. J. Funct. Foods 2014, 10, 407-420. [CrossRef]

66. Suwanmanon, K.; Hsieh, P.C. Effect of gamma-aminobutyric acid and nattokinase-enriched fermented beans on the blood pressure of spontaneously hypertensive and normotensive Wistar-Kyoto rats. J. Food Drug. Anal. 2014, 22, 485-491. [CrossRef] 
67. Wang, H.; Huang, J.; Sun, L.; Xu, F.; Zhang, W.; Zhan, J. An efficient process for co-production of gamma-aminobutyric acid and probiotic Bacillus subtilis cells. Food Sci. Biotechnol. 2019, 28, 155-163. [CrossRef] [PubMed]

68. Vergnolle, N. Protease inhibition as new therapeutic strategy for GI diseases. Gut 2016, 65, 1215-1224. [CrossRef] [PubMed]

69. Da Silva, R.R. Bacterial and fungal proteolytic enzymes: Production, catalysis and potential applications. Appl. Biochem. Biotechnol. 2017, 183, 1-19. [CrossRef]

70. Worsztynowicz, P.; Olejnik-Schmidt, A.; Białas, W.; Grajek, W. Identification and partial characterization of proteolytic activity of Enterococcus faecalis relevant to their application in the dairy industry. Acta Biochim. Pol. 2019, 66, 61-69. [CrossRef] [PubMed]

71. Sarabhai, S.; Tamilselvan, T.; Prabhasankar, P. Role of enzymes for improvement in gluten-free foxtail millet bread: It's effect on quality, textural, rheological and pasting properties. LWT Food Sci. Technol. 2020, 137, 110365. [CrossRef]

72. Dos Santos, M.M.T.R.; de Aguiar, P.F.; Silva, J.B.A.; de Mello, P.P.M.; Sérvulo, E.F.C. Brewery wastes reuse for protease production by lactic acid bacteria fermentation. Food Technol. Biotechnol. 2017, 55, 218-224.

73. Haard, N.F. A review of proteotlytic enzymes from marine organisms and their application in the food industry. J. Aquat. Food Prod. Technol. 1992, 1, 17-35. [CrossRef]

74. Pokora, M.; Eckert, E.; Zambrowicz, A.; Bobak, Ł.; Szołtysik, M.; Dazbrowska, A.; Chrzanowska, J.; Polanowski, A.; Trziszka, T. Biological and functional properties of proteolytic enzyme-modified egg protein by-products. Food Sci. Nutr. 2013, 1, 184-195. [CrossRef]

75. Park, H.; Lee, M.; Ji, Y.; Todorov, S.D.; Holzapfel, W.H. Safety evaluation and in vivo strain-specific functionality of Bacillus strains isolated from Korean traditional fermented foods. Probiotics Antimicrob. Proteins 2021, 13, 60-71. [CrossRef] [PubMed]

76. Montel, M.C.; Masson, F.; Talon, R. Bacterial role in flavour development. Meat Sci. 1998, 49 (Suppl. 1), S111-S123. [CrossRef]

77. El Mecherfi, K.; Lupi, R.; Cherkaoui, M.; Albuquerque, M.A.C.; Todorov, S.D.; Tranquet, O.; Klingebiel, C.; Denery-Papini, S.; Onno, B.; Franco, B.D.G.M.; et al. Fermentation of gluten by Lactococcus lactis LLGKC18 reduces its antigenicity and allergenicity. Probiotics Antimicrob. Proteins 2021. [CrossRef] [PubMed]

78. Biscola, V.; Tulini, F.L.; Choiset, Y.; Rabesona, H.; Ivanova, I.; Chobert, J.-M.; Todorov, S.D.; Haertle, T.; Franco, B.D.G.M. Proteolitic activity of Enterococcus faecium VB63F for reduction of allergenicity of bovine milk proteins. J. Dairy Sci. 2016, 99, 5144-5154. [CrossRef] [PubMed]

79. Wijeyeweera, R.L.; Kleinberg, I. Acid-base $\mathrm{pH}$ curves in vitro with mixtures of pure cultures of human oral microorganisms. Arch. Oral Biol. 1989, 34, 55-64. [CrossRef]

80. Mack, D.R. D(-)-lactic acid-producing probiotics, D(-)-lactic acidosis and infants. Can. J. Gastroenterol. 2004, 18, 671-675. [CrossRef]

81. Todorov, S.D.; Furtado, D.N.; Saad, S.M.I.; Tome, E.; Franco, B.D.G.M. Potential beneficial properties of bacteriocin-producing lactic acid bacteria isolated from smoked salmon. J. Appl. Microbiol. 2011, 110, 971-986. [CrossRef]

82. Todorov, S.D.; Botes, M.; Guigas, C.; Schillinger, U.; Wiid, I.; Wachsman, M.B.; Holzapfel, W.H.; Dicks, L.M.T. Boza, a natural source of probiotic lactic acid bacteria. J. Appl. Microbiol. 2008, 104, 465-477. [CrossRef]

83. De Wouters, T.; Jans, C.; Niederberger, T.; Fischer, P.; Rühs, P.A. Adhesion potential of intestinal microbes predicted by physicochemical characterization methods. PLOS ONE 2015, 10, e0136437. [CrossRef]

84. Schär-Zammaretti, P.; Ubbink, J. The cell wall of lactic acid bacteria: Surface constituents and macromolecular conformations. Biophys. J. 2003, 85, 4076-4092. [CrossRef] 